\title{
SEÑOR, NON SEJAS ATAÚD DE TUS CRIADOS. UNA APROXIMACIÓN A LOS AFINES DEL ENTORNO DE LA CASA DE MOSCOSO (c.1411-c. 1510) ${ }^{1}$
}

\author{
SEÑOR, NON SEJAS ATAÚD DE TUS CRIADOS. AN APPROACH \\ TO THE HOUSEHOLD OF MOSCOSO'S AFFINITY (C. 1411-C. 1510)
}

\author{
CARlos J. Galbán MALAGÓN² \\ Universitat de Barcelona
}

\begin{abstract}
Resumen: El análisis del rol desempeñado por el entorno señorial de la casa de Moscoso a lo largo del siglo XV podría ayudar a aclarar muchas de las opciones y estrategias de afianzamiento desarrolladas en el complejo contexto señorial gallego. Con este fin presentamos una aproximación a determinados aspectos de la relación entre señores y afines.
\end{abstract}

Palabras clave: dinámicas señoriales; afines; casa; Moscoso; Galicia.

\begin{abstract}
The analysis of the role played by the lordship fellows of Moscoso's household throughout the $\mathrm{XV}^{\text {th }}$ century might help to clarify many of the options and strategies of finance in the chaotic Galician context. With this aim we present an approximation to certain aspects of the relationship among lords and individuals, related to the lords in different degrees.
\end{abstract}

Keywords: lordship dynamics; relates; household; Moscoso; Galicia.

\section{SUMARIO}

1. Introducción.- 2. Los miembros de la casa y la configuración del señorío.- 3. Las familias afines.- 4. El cambio de la lealtad.- 5. La deuda como marco de relación entre el afín y el señor.- 6. Entorno y violencia señorial.- 7. Recapitulación. - 8. Apéndice: Afines de la Casa de Moscoso.

\footnotetext{
${ }^{1}$ Amb el suport del Comissionat per a Universitats i Recerca del DIUE de la Generalitat de Catalunya i del Fons Social Europeu.

Abreviaturas utilizadas: $\mathrm{ADM}=$ Archivo Ducal de Medinaceli; $\mathrm{AEM}=$ Anuario de Estudios Medievales; AGS=Archivo General de Simancas; AHDS = Archivo Histórico Diocesano de Santiago; AHUS = Arquivo Histórico Universitario; APDP = Arquivo Provincial Diputación de Pontevedra; ARCHV = Archivo Real Chancillería de Valladolid; ASPA = Archivo de San Paio de Antealtares; CA = José GARCía y María José Portela, La casa de Altamira durante el Renacimiento. Estudio introductorio y colección diplomática, Santiago de Compostela, 2003; $\mathrm{CEG}=$ Cuadernos de Estudios Gallegos; EM = En la España Medieval; TF = Ángel RODRÍGUEZ (ed.), Las fortalezas de la mitra compostelana y los irmandiños, Pontevedra, vol. I-II, 1984; VA =Vasco de APONTE, Recuento de las casas antiguas del Reino de Galicia (M. DíAZ et al., eds.), Santiago de Compostela, 1986.

${ }^{2}$ Queremos agradecer y reconocer toda la ayuda que desinteresadamente nos prestó Julio J. Guardado a lo largo de nuestra investigación, nuestra labor fue mucho más fácil gracias a él. Lamentablemente, hay deudas que ya no podremos pagar. Por otro lado, hemos de agradecer los consejos del Dr. Prim Bertran y de Víctor Muñoz.
} 


\section{INTRODUCCIÓN}

En los últimos años se ha avanzado en el estudio de las principales casas nobles del Reino de Galicia ${ }^{3}$. No obstante, la cas $^{4}$ de Moscoso, cuyo ascenso en el panorama señorial gallego del siglo XV es especialmente rápido, no cuenta aún con un estudio monográfico amplio, si bien cuenta con alguna aproximación relevante 5 . En este sentido, pese al volumen documental a disposición del investigador sólo ha habido un intento claro de trazar la trayectoria de un personaje relacionado con esta casa ${ }^{6}$. En cualquier caso, no deberíamos entender tal progresión como derivada en exclusiva de su habilidad política, de sus alianzas con otras grandes familias, de sus éxitos militares... El control de un territorio y la articulación de un señorío efectivo, sus implicaciones económicas y sociales ${ }^{7}$, se traducen en la necesaria existencia de un personal capaz de vertebrarlo. Esto, nos conduce a contemplar a

\footnotetext{
${ }^{3}$ Ha habido estudios notables, tanto por su calidad como por el volumen documental empleado. Sin entrar en los estudios de conjunto realizados por J. García Oro, destacaríamos Eduardo PARDO, Los señores de Galicia. Tenentes y Condes de Lemos en la Edad Media, vols. I-II, A Coruña, 2000; J. GARcía y M. J. PORTELA, Los Fonseca en la Galicia del Renacimiento. De la guerra al mecenazgo, Noia, 2002; CA y José Francisco CoRREA, A casa de Andrade 1160-1540. Nobreza, mentalidade e ideoloxía na Galicia baixomedieval, Noia, 2009. Este último dedica parte de su investigación al análisis de la estructura familiar de la casa, matrimonios... Ya en Marta GonZÁLEZ, El arzobispo de Santiago: una instancia de poder en la Edad Media (1150-1400), A Coruña, 1996, se presta cierta atención a la problemática del análisis de los linajes de la Terra de Santiago.

${ }^{4}$ Empleamos el término casa atendiendo a la categorización y las precisiones que sobre ello se hacen en: Ignacio ATIENZA, Pater familias, señor y patrón: oeconómica, clientelismo y patronato en el Antiguo Régimen, en Relaciones de poder, de producción y parentesco en la Edad Media y Moderna (R. PASTOR, comp.), Madrid, 1999, pp. 413-416; en la tesis doctoral de Jorge SÁIZ, Guerra y nobleza en la Corona de Aragón. La caballería en los ejércitos del Rey (siglos XIV-XV), Valencia, 2003, pp. 82-84; María Concepción QUINTANILLA, El estado señorial nobiliario como espacio de poder en la Castilla bajomedieval, en Los espacios de poder en la España Medieval: XII Semana de Estudios Medievales, Nájera, del 30 de julio al 3 de agosto de 2001 (J.L. MARTín, dir.), Logroño, 2002, p. 261; Ana María FRAMIÑÁn y Antonio PRESEDO, Estructuras de parentesco de la nobleza gallega en 1350-1600: una primera valoración, "Obradoiro de Historia Moderna", 14 (2005), pp. 119-121 y Víctor MuÑoz, Bandos urbanos y pacificación señorial en la Castilla Bajomedieval: Paredes de Nava y Fernando de Antequera (1400-1416), “AEM", 39/2 (2009), p. 682.

${ }^{5}$ Una aproximación inicial a la trayectoria de la familia con un útil apéndice documental en María Jesús VÁZQUEZ, Los condes de Altamira. Origen, esplendor y ocaso de la ilustre familia de los Moscoso, "Estudios Mindonienses", 10 (1994), pp. 195-279. Sobre los orígenes de la familia de Moscoso vid. Faustino MENÉNDEZ y Eduardo PARDO, A propósito de un nuevo sello medieval gallego. El obispo Don Gonzalo, de Mondoñedo, y los orígenes de la Casa de Altamira, “AEM”, 29 (1999), pp. $803-$ 834 y E. PARDO, La Casa de Altamira y sus linajes en la Baja Edad Media. Viejas noticias y nuevos documentos, en Actas do I Simposio de Historia da Costa da Morte (M. SuÁREZ, coord.), Cee, 2000, pp. 261-282. Paralelamente en Xabier REI y Ana María FRAMIÑÁN, As orixes, a Terra de Nemancos e os Trastámara en Historia de Cee (B. CORES, dir.), A Coruña, 1999, pp. 171-232 e idem, As terras do Concello de Santa Comba na Idade Media en Historia de Santa Comba de Xallas (M. QUINTÁNS, dir.), Santa Comba, 2003, pp. 335-377 y A. M. FRAMIÑán, Notas acerca de los derechos de los laicos en las iglesias parroquiales de Galicia (s.XIII-XV), "Estudios Mindonienses", 21 (2005), pp. 315 378 pueden hallarse numerosas referencias relativas a los Moscoso.

${ }^{6}$ A. M. Framiñán y Xosé Antón García, Os Costela, fidalgos da Casa de Moscoso (séculos XVXVI), "Descubrindo: Anuario de Estudios e Investigación de Deza", 6 (2004), pp. 145-167. Por otro lado, hay un breve análisis de algunas familias ligadas a los Moscoso en Xosé María LEMA y Roberto Mouzo, O Castelo de Vimianzo e os Moscoso de Altamira, A Coruña, 1998, pp. 61-62 y en Carlos BARros, Torres, varas e demos. Os irmandiños da ría de Muros-Noia, Noia, 2009, se dedica cierta atención al papel de García Martiz de Barbeira.
}

${ }^{7}$ M. C. QUinTANILla, El estado, pp. 244 y 250. 
los individuos integrados en las redes sociales del señor. ¿Quiénes participaron en esa expansión?, ¿quiénes, y por qué, lucharon sus batallas? y ¿qué llevó a Vasco de Aponte a poner las palabras que inician este texto en boca de García Martiz de Barbeira? ${ }^{8}$

La amplitud de situaciones, nivel social, modalidad de retribución o el grado de relación, dentro del grupo de los criados obliga, en primer término, a tener en cuenta y reflejar tal diversidad, más allá de los estrictos marcos jurídicos, propios de las modalidades de relación feudo-vasallática ${ }^{9}$. Pese a que no nos es posible considerar en pie de igualdad a todos los individuos al servicio de una casa ${ }^{10}$, máxime cuando éste fluctúa, hay una serie de rasgos comunes que los vinculan a un mismo individuo. Hay un interés mutuo, entre las acciones propias y el engrandecimiento de la casa. Tal relación no elimina cierta libertad de decisión por ambas partes y una gran variabilidad en el propio grado de vinculación o dependencia.

De tal manera, elaboramos una nómina de afines, situados en ese momento de crecimiento de la casa de Moscoso, lo más amplia posible; que pusiera de relieve la continuidad o no de la relación de los individuos con ella y su grado de implicación en las estrategias de consolidación señorial, y que nos permitiera categorizar en la medida de lo posible los tipos de relación entre titular y afín.

\footnotetext{
${ }^{8}$ VA, p. 193.

${ }^{9}$ Interesan pues las reflexiones en torno a los conceptos de bastard feudalism, affinity y vasallaje complejo a partir de la recepción y crítica de los trabajos de Kenneth Bruce MCFARLANE, Bastard Feudalism, "Bulletin of the Institute of Historical Research", XX/61 (1945), pp. 161-168, reimpreso en England in the Fifteenth Century, Londres, 1981, pp. 23-43, con una útil introducción de Gerald Leslie HARRIS, pp. IX-XXVII; Vid. Scott L. WAUGH, Tenure to Contract: Lordship and Clientage in Thirteenth-Century England, "The English Historical Review", 101/401 (1986), pp. 811-839; Peter R. Coss, Bastard Feudalism Revised, "Past and Present", 125 (1989), pp. 27-64; David CROUCH, Bastard Feudalism Revised, "Past and Present", 131 (1991), pp. 165-177; David A. CARPENTER, Bastard Feudalism Revised, ibidem, pp. 177-189 y, especialmente, P. R. Coss, Reply, ibidem, pp. 190-203. También Christine CARPENTER, The Beauchamp Affinity: A Study of Bastard Feudalism at Work, "The English Historical Review", 95/376 (1980), pp. 514-532; Simon K. WALKER, Lordship and Lawlessness in the Palatinate of Lancaster, 1300-1400, "The Journal of British Studies", 28/4 (1989), pp. 325-348; Michael HICKS, Bastard Feudalism, Overmighty Subjects and Idols of the Multitude during the Wars of the Roses, "History", 85/279 (2000), pp. 386-403 y Anne POLDEN, The social networks of the Buckinghamshire gentry in the thirteenth century, "Journal of Medieval History", 32 (2006), pp. 371-394. Vid. asimismo las útiles reflexiones de Thomas N. Bisson, Medieval Lordship, "Speculum", 70/4 (1995), pp. 743-759. Para nuestro ámbito de estudio vid. nota 4 y M. C. QuintanILla, La tenencia de fortalezas en Castilla durante la Baja Edad Media, "EM", 9 (1986), pp. 245-314; Pablo SÁNCHEZ, Nobleza, estado y clientelas en el feudalismo: en los límites de la historia social, en La historia social en España: actualidad y perspectivas. Actas del I Congreso de la Asociación de Historia Social: Zaragoza, septiembre de 1990 (S. CASTILlo, coord.), Madrid, 1991, pp. 207-215; Cristina, JULAR, La participación de un noble en el poder local a través de su clientela. Un ejemplo concreto de fines del siglo XIV, "Hispania", 53/185 (1993), pp. 861-884; Isabel BECEIRO, Criados, oficiales y clientelas señoriales en Castilla (siglos XI-XV), "Cuadernos de Historia de España”, LXXV (1999), pp. 59-84; J. SÁIZ, Una clientela militar entre la Corona de Aragón y Castilla a fines del siglo XIV: caballeros de casa y vasallos de Afons d'Arago, conde de Denia y marqués de Villena, "EM", 29 (2006), pp. 99-102; Pablo S. OTERo y Xosé Antón GARcía, Apuntes de los Ambía: linaje y parentelas ( siglos XII-XVI), “CEG”, LVI/122 (2009), pp. 445-457; José Ignacio ORTEGA, Por seruiçios muchos e buenos que me ha fecho. Los criados de las casas nobiliarias conquenses en la Baja Edad Media, “AEM", 39/2 (2009), pp. 703-721.

${ }^{10}$ Además, hemos de señalar la propia confusión en el ejercicio por parte del entorno de funciones "públicas" dentro del señorío (o relacionadas con el patrimonio), en paralelo con el desarrollo de otras más "privadas" V. MuÑOZ, Bandos urbanos, pp. 683-686.
} 
Para obtener tales datos se recurrió a testamentos señoriales ${ }^{11}$, donaciones, ventas entre particulares, pleitos, concordias y avenencias; también a algunos documentos dispersos relativos a la 'administración señorial' (o a quejas sobre la misma), como la escasa contabilidad señorial, asimismo se hallaron algunas piezas documentales pertenecientes a familias con antepasados ligados en algún momento a la familia Moscoso y, finalmente, a fuentes con un carácter más narrativo que pudieran aproximarnos al desarrollo del servicio a la casa en un contexto histórico más o menos preciso ${ }^{12}$. Estas fuentes provocan ciertas dificultades de partida y explican algunas carencias de nuestro análisis. Dadas las inmensas variaciones en la duración del liderazgo de los líderes del linaje y la variabilidad de la documentación conservada, hay una desigualdad en el número de servidores y afines que se pueden atestiguar para cada titular. La mayoría de documentación "suelta" que empleamos responde a una tipología variada, sin un carácter seriado, con todos los problemas que ello implica para poder extrapolar nuestras conclusiones; aún así su utilidad es mayor al presentar acciones concretas de los propios afines, o acciones señoriales a las que éstos asistían como testigos. Aponte, por su parte, no nos ofrece un relato completo del funcionamiento interno de la casa de Moscoso, sino que atiende a su crecimiento político y a sus relaciones con otras casas con lo que, siendo útil, sólo resalta a determinados afines que participan en estos aspectos. Algo similar podría decirse de los subjetivos testigos del Tabera-Fonseca. Pese a esto, la complementariedad de tales fuentes de información nos permite comenzar a observar procesos de interés en las acciones (y elecciones) de los afines.

Analizar la progresión de los individuos al servicio de los Moscoso, durante los momentos de creación de la propia casa, permite contemplar con cierto detalle el crecimiento de la casa y su posicionamiento político y territorial. Por ello, a lo largo de estas líneas intentaremos exponer y analizar algunos aspectos de su entorno a lo largo del siglo XV y principios del XVI.

\section{LOS MIEMBROS DE LA CASA Y LA CONFIGURACIÓN DEL SEÑORÍO}

En primer lugar, hemos de destacar la labor de los hijos y familiares como parte del entorno de un señor, aunque su relación no sea la misma que la de otros afines puesto que el origen de la relación parte de los lazos de parentesco.

\footnotetext{
${ }^{11}$ Principalmente los de Ruy Sánchez de Moscoso (1454 y 1456), Rodrigo de Moscoso (1458), Álvaro Pérez de Moscoso (1467), Urraca de Moscoso (1498), Lope Sánchez de Moscoso (1500) y Rodrigo Osorio de Moscoso (1507). De los testamentos de Ruy Sánchez se conserva íntegro el de 14 se septiembre de 1454 (AHUS, Clero, Mitra, leg. 133, pieza 19, f.4v y Ibidem, ff.1-3r) y copiado parcialmente el de 31 de julio de 1456 (AHUS, Clero, Mitra, leg. 133, pieza 20, regestado en Manuel LuCAS, El archivo de San Martiño de Fóra o Pinario de Santiago de Compostela, A Coruña, 1999, p. 719), el de Lope Sánchez de Moscoso de 1500 fue conservado y se copiaron las cláusulas que interesaban a Bonaval y otras instituciones (ACS, IG 424). Salvo el último de Ruy Sánchez, el de Rodrigo (un extracto en ASPA, Condado de Altamira, 3A1/ 74, f.3) y el testamento de Álvaro Pérez de Moscoso (AHUS, mic. 34 [ADM, Cillobre, leg. 4, $\mathrm{n}^{\circ}$ 25]) el resto se hallan editados en CA, pp. 90-131. En M. J. VÁZQUEZ, Los condes, pp. 225-227, se prolonga la titularidad de Rodrigo Osorio (muerto en Bujía) hasta 1573, en realidad le sucedería el conde Lope Osorio de Moscoso. Vid. E. PARDO, La Casa de, p. 281.

${ }^{12}$ Una propuesta metodológica similar en I. BECEIRO, Criados, oficiales, pp. 60-63, C. JULAR, La participación, y J. I. ORTEGA, Por seruiçios, pp. 717-720.
} 
La longeva actividad de Ruy Sánchez de Moscoso, explica porqué desgaja aparentemente una parte del señorío de la casa para su hijo Rodrigo ${ }^{13}$. En nuestra opinión esto no implica una pérdida de señorío a favor de un hijo. Se trata de algo más complejo, una forma de consolidar la casa a través de la iniciativa, querida o no, de un individuo dependiente. Así, en la concordia entre Rodrigo de Moscoso y Lope Sánchez de Ulloa en 1448, para casar a Vasco López de Ulloa con Inés de Moscoso (futuros padres de Lope Sánchez de Ulloa o Moscoso, I Conde de Altamira), se establece como dote, entre otras cosas, "çen basalos solariegos de feudo e tytolo da igllesia de Santiago os mays çercanos que meu padre e eu teemos e toueremos...das terras e sennoríos de vos o dito Lope Sanches e de voso fillo"; lo que lleva a pensar que, en el fondo, el señorío de la casa no deja de funcionar conjuntamente como un bloque patrimonial ${ }^{14}$. Esta capacidad para permitir que determinadas parcelas del señorío (tierras, sinecuras, vasallos...) estén bajo la tutela de un familiar se repite en el caso de Juana de Castro que, ya viuda de Rodrigo de Moscoso, es reprendida junto a su hijo, Bernal Yáñez, por tener ocupadas fortalezas arzobispales ${ }^{15}$. Aparece sola cobrando los infinitos de Vimianzo, en 1458, y las alcabalas de Cee y Fisterra, en abril de $1461^{16}$. Al año siguiente es Juana la encargada de intentar igualar a Bernal con Rodrigo de Luna, mostrando el funcionamiento de la casa como un verdadero bloque familiar ${ }^{17}$. Volvemos a encontrarla, junto a Álvaro Pérez de Moscoso, en la avenencia de Alonso de Fonseca II con los caballeros que habían seguido a Bernal Yáñez en el asedio de la catedral de Santiago ${ }^{18}$. Finalmente, en el testamento del propio Álvaro Pérez, se le otorga el señorío del Val da Barcia, y una petición para que no vaya contra la voluntad de su hijo ${ }^{19}$.

Esta forma de organizar el señorío, fraccionándolo, aparece confusamente expresada por Aponte ${ }^{20}$. Otro testimonio similar nos remite a Urraca de Moscoso que, en su última voluntad, pide "por merced al dicho señor Conde que la renta del Val de Barzia non entienda en ella...e me la dexe para cumplir este mi testamento"; esto podría ser una petición normal pero Urraca tiene, además, intereses en otras zonas, Fe-

\footnotetext{
${ }^{13}$ Así se menciona en los señoríos tasados por la Corona en 1451. Amparo RuBio, La Hacienda Real en Galicia en tiempos de Juan II (1406-1454), "EM" 31 (2008), pp. 421-422 y 434.

${ }^{14}$ AHUS, Clero, Mitra, leg. 133, pieza 16, edición de otro ejemplar en CA, pp. 527-529. Ambas partes harán homenaje en manos de Ruy Sánchez.

${ }^{15}$ AHDS, Fondo General, Catálogos, no 2, f. 28r. "Iten otra prouysión del rrey don Enrrique firmada y sellada para que doña Juana de Castro y su hijo entreguen al arzobispo don Rodrigo la Rocha Blanca, Barrojeros e Bienquerençia que en la guerra le tomaron dada a syete de mayo de myll y quatroçientos y çinquenta y nueve años".

${ }^{16}$ AHDS, Fondo General, Bienes y Rentas de la Mitra, 28, f. 84 y ASPA, Condado de Altamira, 3A1/ 86, ff. 1v-2. Un original de este último editado en CA, pp. 329-335.

${ }^{17} \mathrm{ACS}, \mathrm{IG} 703 / 27$, ff.130-131r. Hay que tener en cuenta que previamente una carta de poder de Rodrigo de Luna, ACS, IG 703/28, f. 133, dice que "Por rrason que entre nos e la señora dona Juana de Castro, muger que fue de Rodrigo de Moscoso, et Berrnal Diañes e Aluaro Peres, sus fijos".

${ }^{18}$ Vid. el texto editado en Ermelindo PORTELA et al., Rocha Forte. El castillo y su historia, Santa Comba, 2004, pp. 100-112.

${ }^{19}$ AHUS, mic. 34 [ADM, Cillobre, leg. 4, n 25]. Sobre estas propiedades vid. Bernaldo de Moscoso.

${ }^{20}$ Que indica que los cuatro hijos de Rodrigo y Juana "mandaban la casa (cada uno dellos apartado con su tenençia) aunque a Bernal Diáñez, hijo mayor, todos le obedecían”, VA, p. 174. Hemos de tener en cuenta que Juana de Castro sobrevive a Bernal (m. 1466), y probablemente a Álvaro (t. 1467). La confusión de Aponte, en todo caso, ejemplifica correctamente cómo funciona el señorío. Por ejemplo, "Vernaldo Ianes et seu irmão con toda a cassa de Moscoso" acudieron a ayudar al arzobispo Rodrigo de Luna en Rocha Branca, Rui VÁsQues, Crónica de Santa María de Iria (J. A. SouTO, ed.), Santiago, 2001, p. 57.
} 
rreirós y Labacolla, por cesiones anteriores de Rodrigo de Moscoso y luego de Bernal Yáñez ${ }^{21}$. Lo que indica que la posesión de determinadas propiedades por parte de los familiares al menos debía ser refrendada claramente por cada titular como muestra el testamento de Rodrigo Osorio de Moscoso ${ }^{22}$.

Añadamos otro elemento clave para el señorío como es el asentamiento físico del poder. Las fortalezas propias de la casa son tenidas mediante alcaides, que suelen ejercer la jurisdicción señorial como merinos ${ }^{23}$. Los hidalgos y criados asociados mantienen las fortalezas propias de la casa e incluso, mediante pleito homenaje, facilitan la puesta en tercería de fortalezas para garantizar treguas y acuerdos matrimoniales con otras casas ${ }^{24}$. Del mismo modo, los familiares capacitados para ello se introducen en el sistema de engrandecimiento de la casa al poder recibir la tenencia de fortalezas y terrarias de la mitra compostelana o de otros señores; lo que podía apoyar paralelamente a la constitución de nuevas áreas de influencia a consolidar, como sucede, en cierto modo, con la fortaleza de Vimianzo.

Una vez entendido el modo de reparto del señorío no parece extraña la posibilidad de que, en las fortalezas propias, haya familiares como alcaides, aunque es difícil saber el grado de sujeción que tienen hacia su sangre. Tal vez sea esto lo que indican tanto un testimonio relativo a los abusos cometidos, por Álvaro Pérez, desde la fortaleza de Morgade, como el intento de secuestro en ponte Abargo de la hija de Gómez Pérez das Mariñas; aunque no podemos datar con precisión tales referencias ${ }^{25}$.

\section{LAS FAMILIAS AFINES}

Más allá de los lazos de parentesco, aunque sin excluirlos, aparecen toda una serie de individuos relacionados con la casa pero, a lo largo del marco cronológico estudiado, se tiende a la repetición de varios apellidos al servicio de los titulares: Caamaño, Costela, Corujo, Carantoña, Leis, Lema, Lamas-Coscones, Lesta, O $\mathrm{Campo}^{26}$, Reinoso, Rendal, Riobóo, Sales y Vázquez ${ }^{27}$. A éstos habría que añadirles, siguiendo a Aponte, a la familia Couçeiro de la que no contamos con mayores refe-

\footnotetext{
${ }^{21}$ De hecho tendría un pleito con la mitra, con dos sentencias diferentes, por culpa de estas posesiones. AHDS, Fondo General, Jurisdiccional, 11, cuaderno $4^{\circ}$, doc. 1, Ibidem, Catálogos, $\mathrm{n}^{\circ} 2$, f. 65v y CA, pp. 103-104 y 263-264.

${ }^{22} \mathrm{Si}$ bien con el matiz de que parte de los bienes estaban sujetos a mayorazgo, CA, p. 136.

${ }^{23}$ Las fortalezas poseídas, propias o apropiadas momentáneamente, por los Moscoso a lo largo del siglo XV son: Altamira, Benquerencia, Borraxeiros, Broño, Caldas de Reis, Cances, Cira, Mens, Morgade, Outes, Padrón, Peñafiel, Picosacro, Rocha Branca, Rocha Forte, Val da Barcia, Vimianzo, Xallas, Navia y Burón. Sin entrar a enumerar otras casas y pazos más difíciles de rastrear documentalmente.

${ }^{24}$ Por ejemplo, E. PorTEla et al., Rocha Forte, pp. 103-104 y CA, p. 559. Sobre el uso de la tenencia de fortalezas para la garantía de acuerdos en el contexto bajomedieval, M. C. QUINTANILLA, La tenencia, pp. 871-872.

${ }^{25} \mathrm{TF}$, p. 426 y VA, p. 158. En el primer caso el problema cronológico es importante, dado que de tratarse de una referencia a los años anteriores a 1467 estaríamos ante la situación de que Álvaro Pérez tendría la fortaleza por su hermano, Bernal Yáñez, y podría actuar al margen de su voluntad. En el caso de Abargo, el problema es saber localizar de dónde salió el de Moscoso para atacar a la mujer de Gómez Pérez, ya que pudo ser desde la Torre da Varcia, Morgade, Broño o Altamira.

${ }^{26}$ Este apellido resulta problemático por su larga relación con la familia de Moscoso; empleándose posteriormente para algún hijo natural, como Juan do Campo.

${ }^{27}$ Vid. apéndice.
} 
rencias. Por otro lado, también se hallan los Becerra, pero éstos presentan, además, la particularidad de ser una familia emparentada y relacionada con los Moscoso (y la familia do Campo) ya desde la primera mitad del siglo XIV ${ }^{28}$.

Hay un interés en asegurar la fidelidad de los afines velando por el futuro de sus descendientes, casándolos, integrándolos como criados... Pero también un interés consciente en perpetuar a algunas familias en el entorno de la casa, debido tanto a la procedencia territorial del entorno como a la necesidad de mantener lo más regulado y unido posible el patrimonio de la $\operatorname{casa}^{29}$. De ahí que se tienda a encomendar a los herederos del linaje el cuidado de los criados, y sus descendientes, al igual que se hacía con los vasallos que son el sustento real de la casa. Por ello, la aparición de un mismo criado al servicio de los diferentes titulares del linaje es habitual; si bien no es posible atestiguar correctamente este proceso entre Ruy Sánchez (m. 1456) y Rodrigo de Moscoso (m. 1458).

Pese a la posibilidad de homonimias (o una misma procedencia geográfica), creemos que aún así es un importante indicador del mantenimiento de estas clientelas $^{30}$. Una dificultad añadida es que, en algunos casos en los que se repiten apellidos o nombres, con o sin variaciones, es difícil determinar si estamos ante el mismo individuo, su hijo u otro individuo sin ninguna relación. Desgraciadamente, las características de la documentación empleada, rara vez permiten trazar con exactitud la línea vital de los individuos o un estudio prosopográfico fiable del entorno y sus interrelaciones. En otros casos, en cambio, sí es posible analizar de modo somero cómo progresan algunas familias al servicio de éstos.

Así, el notable García Martiz de Barbeira se casa con Sancha de Lobeira. Con lo que emparenta directamente con un linaje con abolengo, si bien en franca decadencia $^{31}$. Unas referencias a las fortalezas de Outes y Peñafiel en el Tabera-Fonseca, expresan cómo la primera estaba bajo García Martínez de Barbeira, que abusaba de los vecinos de la zona junto a Sancho de Quesende, quien tenía la otra. Se mencionan los abusos, robos y usurpaciones desarrollados desde éstas fortalezas, e incluso en un caso la víctima intenta apelar al conde de Altamira ${ }^{32}$. Pero en el caso de Outes un testigo llega a mencionar que la fortaleza había sido edificada por el propio Barbeira lo

\footnotetext{
${ }^{28}$ Gonzalo Beserra do Val de Veyga y Juan Beçerra do Val de Veiga sirven a Ruy Sánchez. Por su parte a Lope Sánchez de Moscoso le sirvieron Martín Becerra, criado y pariente, y Martín Becerra hijo. Uno de éstos sirve a la casa aún en 1510. Vid. E. PARDO, La Casa de, pp. 277-278 y 282. Hemos de tener en cuenta que podría complicarse el análisis de la relación de esta familia con la casa dado que los Camaño cuentan con un Martín Becerra de Camaño, vid. Fermín BouzA, El señorío de Villagarcía de Arousa desde su fundación hasta su marquesado (1461-1655) (CEG, anexo XV), Santiago de Compostela, 1965, pp. 17 y 20-21.

${ }^{29}$ Vid. sobre la importancia del marco geográfico del señorío para la captación y pago de afines, C. CARPENTER, The Beauchamp, pp. 514-517, A. Polden, The social, pp. 376-383, K.B. MCFARLANE, Bastard, p. x (G. L. HARRIS) y $c f$. pp. 32-33.

${ }^{30}$ Vid. J. SÁIZ, Una clientela, pp. 108-110.

${ }^{31}$ VA, p. 103 y, sobre las vicisitudes de algunas propiedades monásticas de Sancha de Lobeira, Antonio PRESEDO, Las casas nobles gallegas y su relación con los monasterios de la diócesis de Santiago de Compostela en la temprana Edad Moderna (1454-1556), en Galicia monástica: estudos en lembranza da profesora María José Portela Silva (R. CASAL, J. M. ANDRADE y R. J. LóPEZ, eds.), Santiago de Compostela, 2009, pp. 240-241.

${ }^{32}$ Vid. TF, pp. 249, 381-382 y 569-570. Uno de los testigos fue alcaide de la fortaleza por Fonseca II, que tomó Outes a Barbeira. Un análisis de las declaraciones y de la fortaleza en tiempos de Barbeira en Xesús Antonio GulíAs, O castelo de Outes e os monumentos medievais do Barbanza, Noia, 2009 , pp. 11 y 17-25.
} 
que podría interpretarse como el fin de la relación con la casa ${ }^{33}$. En cambio, el interés territorial de la fortaleza para el señorío del Conde de Altamira está claro, se amenaza la zona de Muros, se contrarresta la fortaleza arzobispal del coto de Xallas y se consolida el río Tambre como límite físico de las áreas de influencia. En este caso no importa si la fortaleza se toma para la casa o por iniciativa del afín; puesto que éste, une sus intereses territoriales concretos a la consolidación estratégica de los Moscoso ${ }^{34}$. Si bien la fortaleza acaba en manos arzobispales, un pleito entre Sancha de Lobeira y el arzobispo compostelano zanja definitivamente la cuestión legal, sin implicar una intervención de la casa. No obstante, no podemos saber con certeza en qué fechas se asalta la fortaleza, cuestión de cierto interés, dado que no se menciona ningún intento por parte del Conde de defender o apoyar a Barbeira frente a las tropas arzobispales ${ }^{35}$. Esto sólo permite dos explicaciones, o bien la fortaleza es asaltada en la década de 1470 y la extensión de los conflictos, entre las casa nobles y el arzobispo compostelano, desaconsejaron recuperarla, o lo es a partir de la década siguiente, cuando las relaciones entre el conde de Altamira y la Mitra han llegado a un cierto status quo que permitiría a la casa desentenderse de la fortaleza; dejando al de Barbeira a su suerte, ya que esta actuando a título personal y no como parte del entorno señorial.

Por otro lado, el testamento de Lope Sánchez de Moscoso confirma a Pedro Álvarez, hijo de Barbeira, unos casares que había tenido su padre en el alfoz de $\mathrm{Mu}$ ros, cercanos a la fortaleza de Outes, aunque esto no implica más que una relación con la casa, no necesariamente basada en el servicio; aunque al otro hijo de Barbeira, Juan Alonso, sí se le hace una donación para que se case ${ }^{36}$. También en el mismo documento se menciona la existencia de algún roce judicial previo con García Pérez de Costela, otro de los pilares básicos del condado, que se anula en pro de sus descendientes ${ }^{37}$. Ambos ejemplos, parecen derivar precisamente del recuerdo y consideración por parte de los titulares de la relevancia de un servicio pasado clave para la expansión que protagoniza la casa en la segunda mitad del XV.

Menos espectacular es el servicio de la familia Leis a Lope Sánchez, que termina culminando con la configuración de un patrimonio territorial en torno a un pazo. No se trata de un proceso excesivamente dilatado. Martín de Leis es alcaide y merino de la fortaleza de Altamira, por Lope Sánchez de Moscoso y por Rodrigo Osorio de Moscoso, II Conde de Altamira, incluso llegando a tener cierta relevancia económica para el pago a otros afines ${ }^{38}$. Se le libra de pleito homenaje por la fortaleza en $1505^{39}$. Antes de esto ya mora en la cercana feligresía de Santa María de Trasmonte, en la que adquiere una importante propiedad, en 1494, que se irá transformando en el

${ }^{33}$ Este hecho aparece mencionado como "vna pesquisa del alfoz de Muro y sobre el hurto de la casa de Otes" en AHDS, Fondo General, Catálogos, no 2, f. 38v.

34 "Y Garçia Martiz de Barbeyra con su favor sojuzgaba a Muros y a Noya y al couto de Jallas", VA, pp. 191.

${ }^{35}$ Suceso que habría que datar entre 1477-1481, C. BARROS, Torres, p. 53 (n. 121).

${ }^{36}$ Vid. Apéndice. Respecto a Pedro Álvarez CA, p. 113, el hecho de no incluirlo como afín es precisamente porque la donación es reversible pero se indica que sí la donación original era perpetua se mantenga; lo que puede estar indicando que Juan Alonso sí había sido encomendado a la casa y su hermano no.

${ }^{37}$ CA, p. 114 .

${ }^{38}$ En el libro de acostamientos de 1510 aparece mencionado dos veces en relación con el pago de otros acostamientos y prestanças.

${ }^{39}$ APDP, Fondo Especial 1-Familia Caamaño, 1270/ 32, ff. 4 r-6. 
futuro pazo $^{40}$ (si bien la propiedad podría haberla poseído, con anterioridad, Rodrigo o Ruy de Leis $)^{41}$. Esta información del servicio a la casa y culminación de la progresión familiar se conservaría en la propia memoria de sus descendientes, firmemente afincados en el pazo de Leboráns, aún a principios del siglo XVII ${ }^{42}$.

Hemos mencionado, entre las familias al servicio de los Moscoso, a los Carantoña y también tenemos noticia de la familia Caamaño (más relacionada con los Moscoso en época moderna $)^{43}$. Ambos apellidos podrían proceder de un mismo tronco familiar, ya sea porque alguno de los descendientes fuera hijo natural o por un fraccionamiento del propio linaje por otros motivos que desconocemos. Como apoyo a tal hipótesis, contamos con una pesquisa, realizada a petición de Alonso de Mendoza, sobre las exenciones de determinadas propiedades en Noal y Carantoña. Curiosamente aparece como propietario de ellas un Rui Ferrandes de Caamaño, denominado escudeiro en la pesquisa de Noal, pero en la de Carantoña es "señor do dito [so]lar" 44 . Se trata de un escudero que tiene una prestança de la mitra en tiempos de Lope de Mendoza, relación que mantendrá su hijo García de Caamaño el viejo, que llegó a participar en los sucesos de Corcubión ${ }^{45}$. Por el testimonio de los testigos de la pesquisa se deduce una propiedad prolongada de la familia en aquellos lugares, pero aún así no se menciona relación alguna con los Moscoso; en cambio sí que conocemos la relación de este primer Caamaño con la mitra compostelana y con las villas de Muros y Noia ${ }^{46}$. No obstante, en 1438 casa a su hija con Fernán López de Lamas, criado de Ruy Sánchez, con lo que, como mínimo, hay una relación con la casa que otros familiares pueden explotar con éxito; puesto que García de Caamaño sirve al II Conde de Altamira. Así, Rui Peres de Carantoña sí hace mención directa de relación con la casa en su testamento ${ }^{47}$. Otros indicios de posible de afinidad los tenemos en la tendencia a la homonimia en los linajes y la coincidencia del apellido Caamaño en relación al solar de Carantoña, con lo que la solución onomástica, de que determinados individuos se denominen por el solar y no por el apellido familiar, aparece como opción plausible, aunque no siempre segura. Dada la falta de

${ }^{40}$ Ibidem, ff. 6 v-9 r. Hay que recordar que Trasmonte es la parroquia vecina a Brión donde se halla la fortaleza.

${ }^{41}$ Ibidem, f. 17. El testigo Pedro Ares dice que de "quarenta años a esta parte este testigo que depone siempre vio usar e tener a Martín de Leis de [f.v] Leboráns e a su mujer Mencía Vázquez en el palacio tejado...y ansimesmo que oyó decir que fuera de su padre Rodrigo de Leis".

${ }^{42}$ La documentación alusiva a Leboráns fue copiada a petición de Martín de Leis de Leboráns y Montenegro, bisnieto de Martín de Leis. Ibidem, f. 2r.

${ }^{43}$ También cabe señalar que tanto Caamaño como Carantoña son dos topónimos que aparecen en el territorio de Postmarcos. Un indicio en contra es la existencia de un Carantoña en la zona de Vimianzo, lo que además se ve apoyado por una permuta, entre Fernán Álvarez de Carantoña y Lope Sánchez de Moscoso, de San Mamede do Monte por Loalo (Muxía) que vendría a indicar que los Carantoña al servicio de la casa procederían de la zona norte de la provincia de A Coruña.

${ }^{44}$ APDP, Fondo Especial 1-Familia Caamaño, 1192/ 13, cuaderno suelto " $\mathrm{n}$ '1355" e ibidem, 1270/ 32, cuaderno suelto. Hay que tener en cuenta que Ruy Fernández estaría entre los caballeros que 'siguiendo' a Rodrigo de Moscoso se negarían a acudir en 1458 al llamamiento del arzobispo para ir a la guerra, ACS, LD 19/13, ff. 2-3v (11v-14r). Hay constancia de dos Roy Fernandes de Caamaño escuderos que atestiguan ante Suero Gómez de Sotomayor, en 1454, el hijo de uno de ellos reciben el mismo feudo de iglesia que tuvo su padre A. RODRÍGUEZ, Documentación medieval del Archivo Histórico Diocesano de Santiago "Libro de feudos de diferentes bienes, feligresías, cotos y jurisdicciones", “Compostellanum”, XXXVII/34 (1992), pp. 421-422 y 427-428.

${ }^{45}$ F. BouZA, El señorío de Villagarcía, pp. 99-100.

${ }^{46}$ A. Rodríguez (ed.), O Tumbo Vermello de Don Lope de Mendoza, "Cuadernos de Estudios Galegos", anexo XXIII (1995), p. 137 y CA, p. 535.

${ }^{47}$ Vid. apéndice. 
documentación clara al respecto, no podemos ir más allá en el análisis de ambas ramas, ni categorizar su ascenso dentro de la casa, aunque parece claro que se trata de una familia de pequeños hidalgos que consiguen situar, por un lado, a varios de sus miembros en el entorno de los Moscoso, alguno de ellos con gran notoriedad, y, por el otro, relacionarse con la mitra compostelana.

\section{EL CAMBIO DE LA LEALTAD}

La situación de fidelidad de los afines por definición no es un proceso unidireccional. Permite situarse en el entorno de una casa, sin embargo también interactuar con otros señores. En esta última dinámica cabría situar el propio señorío arzobispal, que atrae tanto a los titulares de grandes linajes como a las pequeñas familias de hidalgos y escuderos que "florecen" en el ámbito de la Terra de Santiago ${ }^{48}$.

No siempre el servicio a uno de los señores de la casa implica una lealtad constante a sus sucesores, ni siquiera cuando hay relación de sangre entre afín y señor ${ }^{49}$. La duración parece derivar más del interés de ambas partes que de otras consideraciones. Así, Esteban de Xunqueiras es nombrado cumplidor del testamento de su primo, Álvaro Pérez de Moscoso, en octubre de 1467, pero está relación con la casa no le impide participar, y ser herido, en el primer asalto a la fortaleza de Altamira tres años después ${ }^{50}$. Esto deriva de que si bien el testamento de Álvaro Pérez daba a Lope Sánchez un señorío amplio, parte de él se hallaba en disputa con el arzobispo compostelano, al que realmente servía en ese momento Xunqueiras o al que más le interesaba servir en esa coyuntura ${ }^{51}$. Del mismo modo, el afianzamiento de la casa explica que Xunqueiras aparezca algunos años después como alcaide de la misma Altamira ${ }^{52}$. No es el único caso de cambio de posición: cinco escuderos de Lope Sánchez de Moscoso, entre ellos Lope do Cádavo, intentaron capturarlo cuando éste se hallaba en Cira, siendo clave para su supervivencia García Martiz de Barbeira ${ }^{53}$. Según Aponte esto procede de la falta de influencia que tienen sobre su señor frente al protagonismo de

${ }^{48}$ De hecho, M. GONZÁLEZ, El arzobispo, pp. 164-175 y Mercedes VÁZQUEZ, El arzobispo don Alonso II de Fonseca Notas para su estudio, CEG, t. XLVII, fasc. 112, 2000, pp. 124-126 plantean reflexiones útiles sobre la necesidad del desprendimiento arzobispal para captar y vincular a los caballeros de sus señoríos.

${ }^{49}$ Esto ha sido atestiguado recientemente en los Andrade, vid. J. F. CORREA, A casa de Andrade, pp. 390-392. Por otro lado, también se ha señalado, en la caracterización de la baja nobleza, que "Dependencia vasallática y relaciones clientelares respecto de otros nobles no comportan la integración en las redes parentelares y patrimoniales del linaje superior", Reyna PASTOR et al., 1994, Baja Nobleza: aproximación a la historiografía europea y propuestas para una investigación, "Historia Social", 20 (1994), pp. 23-45.

${ }^{50}$ AHUS, mic. 34 [ADM, Cillobre, leg. 4, no 25] y VA, p. 182. También participaría en la toma de la fortaleza de Outes contra Barbeira. Vid. X. A. GULÍAs, O castelo, pp. 25-26 y 59.

${ }^{51}$ Sobre el papel jugado por Xunqueiras en un conflicto posterior del arzobispo relativo a Rianxo vid. AHDS, Fondo General, Catálogos, n 2, f. 31v. En 1502 se excluye del partido del Conde de Altamira la zona que correspondería a "Estevan de Junqueyras e de los suyos”, José GARCÍA, Galicia en la Baja Edad Media. Iglesia, señorío y nobleza, Santiago de Compostela, 1978, p. 277. Sobre la relación de Xunqueiras con la zona de Pobra do Deán, vid. A. M., FrAmiñÁn, Notas, pp. 337-338 (n. 100) y 340.

${ }^{52}$ El documento (AGS, Registro General del Sello, 1480, 10, f. 168) hace referencia a que sería alcaide al menos desde seis años antes.

${ }^{53}$ VA, pp. 191-192 y 196-197. Juan Rodríguez de Ocampo, emparentado con los Moscoso, retornaría al servicio de la casa, mientras que Juan Rodríguez de Sales fue ahorcado por el conde. 
Barbeira. Al margen de ello, lo que resulta llamativo es el interés de estos escuderos en pasarse al bando arzobispal, y la posterior reconciliación con el conde de uno de ellos.

Otro individuo con una relación peculiar con la casa de Moscoso es Lope Pérez de Mendoza ${ }^{54}$. Casado con doña Urraca de Moscoso, en tiempos de Rodrigo de Moscoso, y fallecido al tiempo de la revuelta irmandiña. No obstante, la relación con la casa no es constante pues tenemos una referencia, sin fecha, de que varios caballeros, entre ellos el propio Rodrigo de Moscoso, le dieron "vna carta de seguridad" 55 . También tiene, en 1456, por el arzobispo Rodrigo de Luna, las fortalezas de Mesía y Cira ${ }^{56}$. Dos años después se resiste a devolverlas, lo que puede entenderse por su participación en el manifiesto de Antealtares contra el arzobispo, hasta que recibe garantías respecto a las fortalezas ${ }^{57}$. En principio su relación de afinidad es variable, no es precisamente un personaje irrelevante (tiene casa propia), ya que vela por su propio interés, sirviendo o enfrentándose con el arzobispado hasta que, con el matrimonio con Urraca, recibe un señorío de la casa. Esto nos permite entender una relación de afinidad con la familia de su mujer, como testimonia una deuda, reclamada en el testamento de Álvaro Pérez de Moscoso, que tenía con Bernal Yáñez. De hecho, su implicación va más aún, puesto que participa en las estrategias de afianzamiento de la casa justo antes y durante el período irmandiño ${ }^{58}$. Así, una posible consecuencia de su relación con la casa es la apropiación de la fortaleza de Cira por el primer conde de Altamira, derivando del recuerdo de que los Moscoso controlaban tal fortaleza antes de 1467-146959.

Por todo ello, estos cambios de posición individual tienden a favorecer a la casa. El propio García Martíz, parece hallarse en 1456 en el entorno del arzobispo Rodrigo de Luna ${ }^{60}$. El escudero Pedro de Neveiro, parece relacionarse con la casa de Montaos en 1449 pero, en 1458, lo hallamos en la catedral como representante directo de

${ }^{54}$ O de Moscoso o Mesía. Su sepulcro se halla actualmente en el claustro de la Catedral de Santiago. Vid. E. PARdo de GuEvarA, Los señores, vol. I, p. 361, AHDS, Fondo General, Catálogos, $\mathrm{n}^{\circ} 2$, f. 48r, Mercedes VÁZQUEZ, El libro memorial de pleitos del Arzobispo Alonso de Fonseca III, "Compostellanum", XLIII/1-4 (1999), p. 721 (Ejemplar dedicado a: En Camino hacia la gloria (Miscelánea en honor de Mons. Eugenio Romero Pose), Luis QUINTEIRO FIUZA, Alfonso J. Novo CID-FUENTES, coord.) y CA, pp. 480 y 485.

${ }_{55}^{5}$ AHDS, Fondo General, Catálogos, n 2, f. 39r. En el mismo se aluden más problemas con el arzobispo Rodrigo de Luna. En VA, p. 175, se alude a que un Moscoso le prendió en Boente.

${ }^{56}$ AHDS, Fondo General, Catálogos, no 2, ff. 29v, 37v y 58v y M. VÁZQUEZ, El arzobispo, pp. 714, 716 y 720 .

${ }^{57}$ Consistentes en "vn omenaje que el arçobispo don Rodrigo hizo...de no le pedir en su vida las fortalezas de Mexia y Çera”. AHDS, Fondo General, Catálogos, n², f. 36 r. En esto Lope Pérez fue amparado por el propio rey. En el manifiesto de Antealtares coincide con Bernal Yáñez y Juana de Castro, vid. J. GARCía y M. J. PORTELA, La Casa, pp. 529-536 y María Carmen PALlARES y Ermelindo PORTEla, Compostela y la revuelta de los irmandiños, en Universitas. Homenaje a Antonio Eiras Roel (C. FERnÁndeZ, D. L. GonZÁlez y E. MARTíneZ, eds.), t. I, Santiago de Compostela, 2002, p. 91.

${ }^{58}$ Vid. ACS, IG 705/16, ff. 135-136. Hay que tener en cuenta que es parte en el concierto de 1466 con el arzobispo y que sus intereses en las fortalezas arzobispales se centran en una zona diferente a la de los Moscoso pero complementaria a Cira, vid. nota 16, M. VÁzQUEZ, El libro, p. 709 y R. VÁSQUES, Crónica p. 58. Nótese que, para Rui Vázquez, las muertes de Bernal, Álvaro y Lope, en parte se relacionan con sus acciones conjuntas contra la Iglesia de Santiago.

${ }^{59} \mathrm{Cf}$. Carlos José GALBÁn, El señorío de los Moscoso y el surgimiento de la fortaleza de Altamira (Brión, A Coruña), en Les senyories a la Catalunya baixmedieval (ss.XIII-XV). Actes del I Seminari d'Estudis Medievals d'Hostalric (13-14 de novembre de 2008, Hostalric), (A. MARTínEZ, N. PUIG y M. VIADER, eds.), Hostalric, 2009 p. 152.

${ }^{60}$ AHUS, Clero, Mitra, leg. 133, pieza 21, f. 25r. 
Rodrigo de Moscoso ${ }^{61}$. Y García Pérez de Costela, amo de Lope Sánchez de Moscoso, podría haber servido, como escudero, primero a los Ulloa (en concreto a Vasco de Ulloa, padre de Lope), apoyando y ayudando al que sería el I Conde de Altamira ${ }^{62}$. Además, Aponte nos narra que el encumbramiento de Lope Sánchez, como titular de los Moscoso, se debe a la elección de los hidalgos de su casa pero, como ya han señalado A.M. Framiñán y X. A. García, el testamento de Álvaro Pérez de Moscoso lo instituye como heredero ${ }^{63}$. Tal vez habría que ver en esta aparente contradicción, una expresión del concepto que el propio Aponte tiene del papel jugado por los afines; no son en realidad un grupo de grandes señores, pero sí constituyen la fuerza tangible del titular y su señorío.

Contamos también con el caso del hidalgo Gutierre de Hevia, asturiano de origen $^{64}$. En 1511 es alcaide de la fortaleza de Altamira ${ }^{65}$. Tras esto se convierte en alcalde mayor del condado. Durante este período hay algún encontronazo, al margen de los numerosos pleitos, en la zona de Altamira con los representes arzobispales, derivado de las tensiones por la legitimidad o no del señorío de Altamira, por lo que Gutierre de Hevia iba acompañado de un séquito propio, por mandato de sus señores, con "syete u ocho proves e un escudero que yo traya de contino adonde quiera que estaba" $"$. Curiosamente en el año 1524, se da una toma de posesión de las fortalezas arzobispales y se entregan, en Melide, varias armas a un tal Gutierre d'Ebya como representante arzobispal ${ }^{67}$. Podríamos pensar que el servicio de los Hevia a los conde de Altamira había terminado de mala manera, pero un tal Rodrigo d’Ebia será merino de la fortaleza de Altamira en 1558 y $1562^{68}$. No fue un caso único ${ }^{69}$.

Pese a lo que podría parecer, hay indicios para pensar que los cambios de lealtad no sólo se dan en figuras relevantes del entorno señorial. En julio de 1457, las tropas arzobispales habían atacado y saqueado la villa de Corcubión (en la que se hallaba Juana de Castro); entre los acusados de participar en el ataque y en los agravios recibidos por los Moscoso, incluyendo la muerte de un escudero de la casa, se hallan García de Caamaño el viejo y su hermano, Martín Beserra, con su criado Iohan $^{70}$.

${ }^{61}$ Vid. Apéndice.

${ }^{62}$ Esta hipótesis en A. M. Framiñán y X. A. GARcía, Os Costela, p. 148. Vid. nota 214.

${ }^{63}$ Ibidem, pp. 151-153 y VA, p. 179. Cabe no olvidar que ya en tiempos de Rodrigo de Luna, Lope Sánchez de Ulloa el mozo, o de Moscoso, cobra cierta relevancia para la casa en 1459, ya que el arzobispo intenta asociarlo a las propiedades de su padre, Vasco de Ulloa, prometiéndolas tanto a los Moscoso como a los Ulloa ACS, IG. 703 / 28, f. 133 y AHDS, Fondo General, Bienes y Rentas de la Mitra, 3, f.135. De aquí deriva la disputa entre Juana de Castro y Lope Sánchez de Ulloa por la tutela del futuro I Conde de Altamira, CA, p. 499.

${ }^{64}$ Hay un perdón real concedido en 1476 a Gutierre de Hevia, hijo de Gutierre de Hevia y vecino del Principado de Asturias, por servir en la guerra con Portugal, sin que quede claro si se trata del mismo individuo analizado aquí. AGS, Registro General del Sello, 1476, 5, f. 336 y AHDS, Fondo General, Catálogos, n 2, f. 69r.

${ }^{65}$ CA, p. 434.

${ }^{66}$ Ibidem, pp. 383-384. El enfrentamiento con el arzobispo debió tratarse de un acto de bandidaje por parte de las tropas arzobispales. Reflejado indirectamente también en fuentes arzobispales, vid. ACS, IG 711/4, ff.27r y 31r. Referencia al relajamiento de este conflicto después de 1510 en M. VÁZQUEZ, El libro, p. 717.

${ }^{67}$ Pese al problema de las homonimias cabe destacar que en 1520 Gutierre acude a la reunión anticomunera de Melide "en nombre y con poder del conde de Altamira y de su curador el obispo de Astorga”. Vid. ACS, IG 711/4, f. 31v e IG 705/17, f. 137r, cita de otro ejemplar de la reunión en J. F. CORREA, A casa, 567 (n. 1872).

${ }^{68}$ Vid. Gutierre de Hevia.

${ }^{69}$ A. M. Framiñán y X. A. García, Os Costela, pp. 166-167.

${ }^{70}$ CA, pp. 536-544 y ASPA, Condado de Altamira, 4, f. 29 r. 
¿Cabe la posibilidad de que sea el mismo Martín Becerra que serviría, con su hijo, a Lope Sánchez de Moscoso? La respuesta es que nada impide que así sea.

Esta capacidad de los afines, abandonar la fidelidad a la casa o retomarla, también se revelaba como un recurso útil para el titular en aras de reforzar alianzas o comprometerse al cumplimiento de algún acuerdo con otro noble. De tal manera, el 11 de mayo de 1478, Alonso Díaz de Pedrosa, Alonso de Zamora, Fernán de Taliño, Francisco de Reinoso, Gonzalo Pérez de Gori, García Teçeyro, Lope Rodríguez, Lope de Budal, Pedro de Quixada y Ruy de Fidelairo "fidalgos, escuderos e criados que somos del señor Conde de Altamira, de su liçencia y espreso mandado...fasemos pleito e omenaje... a vos el magnifico señor Conde de Benavente", pero este acuerdo fue transitorio ya que algunos de los participantes continuaron su servicio a la casa ${ }^{71}$.

En algunos casos los afines interactúan con otros señores en virtud de su condición como representantes de los intereses de sus patrones. En este caso, se supone que actúan como miembros de la casa comprometiendo su palabra. Así, conocemos "vn juramiento que hiço Diego del Campo merino de Altamira de no pertubar la juridiçión de la iglesia"72. Aunque el contexto de la propia casa, con posterioridad al II Conde de Altamira, dotaba de mayor autonomía a los cargos de la administración señorial (por la tutoría de Pedro Bermúdez, implicación en las campañas africanas de los condes y aumento del señorío de la casa, con la lenta pérdida de interés por el patrimonio gallego de la misma).

Esta facilidad para el cambio de lealtad, su inestabilidad, puede explicar algún caso de difícil comprensión. Por ejemplo, en una carta dirigida al conde de Altamira en 1486 sobre usurpaciones al monasterio de San Xulián de Mourence, se menciona a muchos individuos (algunos atestiguados en otra documentación como afines), se indica que ha usurpado cada uno en concreto, pero entre ellos está abad de San Paio de Antealtares ${ }^{73}$. En este caso no creemos que se trate de una lealtad prolongada sino de una relación coyuntural, aunque la relación de los Moscoso con San Paio no lo era ${ }^{74}$. Incluso, Juan Prego, regidor de Noia a principios del XVI, parece que abandonó la casa tras la muerte de Bernal Yáñez ${ }^{75}$.

\section{LA DEUDA COMO MARCO DE RELACIÓN ENTRE EL AFÍN Y EL SEÑOR}

Por más que, mayoritariamente, la dependencia directa de los criados para con el señor sea la relación más común, hay otros modos más sutiles: las deudas y la relación económica. No es fácil ver el papel jugado por éstas en la interacción de ambas instancias, a caballo entre la negociación y la redistribución de recursos ${ }^{76}$. Pensemos que, a una escala

\footnotetext{
${ }^{71}$ Una interpretación distinta de este cambio de lealtad en I. BECEIRO, op. cit., p. 76 (n. 50) y M. C. QUINTANILLA, Élites de poder, redes nobiliarias y monarquía en la Castilla de fines de la Edad Media, "AEM", 37/2 (2007), p. 966. Vid. M. J. VÁzQUEZ, Los condes, pp. 242-245. Nótese que Francisco de Reynoso, vid. Apéndice, acabaría teniendo gran relevancia para el Conde de Altamira. CA, pp. 548-550 (la edición de este documento en M. J. VÁZQUEZ, Los condes, pp. 254-257 puede resultar problemática). Vid. más adelante.

${ }^{72}$ Vid. Diego de Ocampo.

${ }^{73}$ Vid. Alfonso Gómez de Vilar de Francos.

${ }^{74}$ A. PRESEDO, Las casas, pp. 234 y 236, una donación ya de Ruy Sánches en AHUS, Clero, legs. 823 , f. 61 que además escogería el monasterio para ser enterrado. Tengamos en cuenta, entre otras cosas, que en 1491, la condesa de Altamira había sido enterrada allí, pese a su posible suicidio y los problemas que éste acarreaba al convento, ACS, IG 705/59, ff. 411-412.

75 Vid. apéndice.

76 P. SÁNCHEZ, Aspectos de una teoría de la competencia señorial: Organización patrimonial, redistribución de recursos y cambio social, "Hispania", LIII/185 (1993), pp. 890-892.
} 
superior, Fernán Pérez de Andrade, según Aponte, ayudaba económicamente a Bernal Yáñez de Moscoso ${ }^{77}$. Pero esta capacidad de endeudamiento mutuo, del señor y su entorno, no daña la estructura de la casa. De hecho, la deuda refuerza la permanencia de los afines, puesto que lo único que podría asegurar el cobro de deudas contraídas con el titular de la casa era la relación con el siguiente titular; como evidencia la reiteración en los testamentos de que se paguen mandas de antepasados. Parece un fenómeno de retroalimentación, ya que los testamentos son bastante claros en la existencia de donaciones reversibles que salvaguardaban el patrimonio de la casa ante la posibilidad de que el beneficiado abandonase al siguiente titular. Este tipo de donación no es más que el pago por servicios prestados, o la compensación a la viuda de un criado...y solían durar la vida del beneficiado y no implican el traspaso de señorío. Esto mecanismo sirve también como vía de incorporación de nuevos afines puesto que hay una inercia a que los bienes donados, o el disfrute de los mismos, a un criado volvieran a entregarse a sus descendientes y parientes ${ }^{78}$. Por otro lado, la relación con los afines permite situaciones a la inversa, recibiendo el señor una donación o la administración de determinados bienes, siempre salvando aquello que se debiera a los familiares del dependiente por herencias, pero esto no implica que el señor haya de devolver la posesión, sólo afrontar los gastos derivados de la misma ${ }^{79}$.

Así, también es común, en la relación afines-titular, el recurso a censos, ventas, permutas o arrendamientos. Estos mecanismos permitían crecer a la casa, aun a costa de otros señoríos mediante la participación de miembros del entorno en otras clientelas. La relación de afinidad de los Becerra con Ruy Sánchez de Moscoso se ve reflejada en una usurpación de unas feligresías del arzobispo que se hizo "sin titulo alguno... deziendo que las conpro de Gonzalo Bezerra de Val de Veyga, fijo de Martin Bezerra". Lo que resulta relevante porque ninguno de ellos tenía título alguno, a lo que el propio arzobispo "dio lugar a ello por el seer vuestro criado"

Pero hay otros mecanismos, el testamento de Álvaro Pérez de Moscoso nos habla de las prestanças En principio lo contemplamos, erróneamente, como meros préstamos o pagos del servicio, pero parece tratarse de una situación algo más compleja $^{81}$. El término alude también a un apoyo de los afines a los Moscoso, un tipo de préstamo que podía ser reversible o no, y que lleva asociado el pago de una cantidad al afín (o la cesión de unas rentas o un beneficio para lo mismo), aunque no podemos saber la regularidad del pago, ni su porcentaje respecto a lo cedido, dado que las

77 J. F. CORREA A casa, p. 388. Cabe tener en cuenta la propia perspectiva de Aponte como afín de los Andrade.

${ }^{78}$ CA, pp. 119 y 136. "Yten es mi voluntad que Afonso Lopez de /Sayabedra, hijo del señor Fernd Dares de Sayabedra, que Dios aya, llebe el mi coto de M. (sic), que fue de su padre, con todo lo que yo siempre en el llebe. Y si el dicho Afonso Lopez falleciere menor de edad quiero que lo llebe y aya su hermano Pedro, y si este falleciere menor de edad ayalo la señora doña Costanza, fija del dicho señor Fernando Dares, o quien della decendiere".

${ }^{79}$ Ibidem, p. 125.

${ }^{80}$ A. RodríGUEZ (ed.), O Tumbo, p. 142. En la misma se menciona una terraria que Juan Becerra tenía de la mitra y la había usado para dotar a su hija para casarla con un Andrade. Un caso similar en A. M. Framiñán, Notas, p. 377.

81 "Yten mando, a Juan Rodrigues de Salnés, fillo de Áluaro Gomes, os casares que min ten en prestança Tareyja de Córdova". Pedro también: "Yten mando que pague a Lope de Cádavo tres mill pares de blancas que lle devo de súa prestança, e diez mill a Lopo Peres Marinno, e tres mill a Áluaro de Camanno", más adelante en el mismo documento se indica que "Yten mando, que mev conpridor colla e lleve todas las rrentas [f.v] e dreyturas, asy préstamos de escudeyros conmo esto que eu mando en esta miña manda, como outras quaesquer cousas que eu aja de rrenta, o prymeyro año de noso faleçemento para ajuda de conplyr las mandas de meus señores aboo e padre, e as miñas e de meu yrmano". Aunque con el sentido de préstamo aparece también en el testamento de Lope Sánchez, CA, p. 113. Vid. A. M. Framiñán, y X. A. García, Os Costela, pp. 162-163. 
mandas testamentarias podían cubrir varios años de impago. Si pensamos que Lope de Cádavo tiene una prestança con Álvaro Pérez de Moscoso, hemos de entender que había una relación de afinidad entre ambos, de hecho mantenida con posterioridad, ya que Lópe de Cádavo serviría como escudero a Lope Sánchez de Moscoso. Así, a Franciso de Reinoso se le prometen como dote $400.000 \mathrm{mrs}$ pero para garantizar el pago se le dan en prenda un privilegio que tenía el conde sobre las alcabalas del vino de Pontevedra y, también, lo que poseía el conde en la feligresía de Vedra pero, en este caso, la confusión entre dote, prestança y servicio muestra el carácter amplio de una relación basada tanto en el patronazgo señorial como en la retribución al afín ${ }^{82}$. Una relación similar debió tener Aparicio Borrallo con Juana de Castro y Bernal Yáñez de Moscoso, porque se le debía, aún en 1500 , una deuda ${ }^{83}$.

No aparecen prestanças en todos los testamentos; pero su utilidad para la casa queda reflejada cuando Lope Sánchez de Moscoso, al pedir en 1469 que se le nombren nuevos tutores, se queja de que sus anteriores tutores "avia feito çertas donaçoos e arrendamentos e vendas e desenbargos e dado prestanças e outros maaos tratos dos ditos seus bees e fasenda" ${ }^{84}$. Si tenemos en cuenta las implicaciones de la creación y mantenimiento de un entorno, Lope, en realidad, está intentando mantener los resortes económicos necesarios para consolidar el servicio de anteriores afines y evitar el desmantelamiento de su casa en un momento conflictivo, pese a que no contemos con un listado en estos momentos de los individuos relacionados con la misma. Esto sucede precisamente por el irregular acceso a la titularidad de Lope y la aparente debilidad de los Moscoso. En cambio, justo después de la muerte del II Conde de Altamira, 1510, ya contamos con un resumen sistemático de quienes tenían este tipo de relación con la casa, y no se centra solo en el servicio militar sino que se incluye algún bachiller y escribano que ejerce de su oficio ${ }^{85}$. De la misma manera, a principios del XVI se anota qué beneficios tiene la casa y quién los lleva, lo que sí permite hablar de un pago en rentas por servicio pero no permite generalizarlo a todo el entorno ni establecer que es la única modalidad de retribución. Ambas iniciativas obedecen, además, a los propios cambios administrativos del señorío que buscan una racionalización y una regulación del funcionariado señorial ante posibles abusos, "que lo que se ha de gastar en muchos se gastase en un hombre honrado" $"$.

Respecto al acostamiento, hemos de señalar que se tiende a la confusión con la prestança, e incluso con el pago asociado por tener una fortaleza (tenençia). Pero se considera algo usual como relación del afín con el señor incluso cuando se trata de un servicio concreto ${ }^{87}$.

\footnotetext{
${ }^{82}$ Pese a que la cantidad es "por sufragio de vuestra honra, sustentación e persona por razón del dicho casamiento e serviçios" se añade que "quanto mi voluntad es de vos los dar e doy en prestança" ARCHV, Pergaminos, Carpeta 163, 5.

${ }^{83}$ En este caso la situación se complica, vid. Aparicio Borrallo.

${ }^{84}$ CA, p. 545.

${ }^{85}$ Ibidem, pp.467-476. Puede verse como la libranza de los pagos podía requerir, además, intermediarios que pueden ser otros afines. La menor presencia de letrados en los primeros momentos de la expansión señorial deriva, en nuestra opinión, de la dificultad de establecer la afinidad de determinados notarios y escribanos en la documentación.

${ }^{86}$ Así lo indica el informe de 1530 del bachiller Cuéllar, CA, pp. 316-318. Lo que tiene sentido a la luz de casos como el de Gómez de Ventosa o Gutierre de Hevia, precisamente en tiempos del II Conde de Altamira.

87 "a todo vuestro serviçio e mandado e vos seguiremos e serviremos donde, como e segund e por la forma, vya e manera que vos quisierdes...y a nos posyble fuere, dandonos nuestro sueldo e acostamiento segund es acostumbrado en este Reyno de Galisia”, Ibidem, p. 549. Aponte aporta
} 
En este sentido, contamos también con la soldada como mecanismo de retribución por el mantenimiento del servicio, Lope Sánchez de Moscoso establece el pago a dos de sus servidores, incluyendo a la mujer de uno, estableciendo la posibilidad de dejar el servicio a la casa, a no ser que Rodrigo Osorio quiera mantenerlos a su servicio ${ }^{88}$. Pero en estos casos la soldada es una retribución destinada en apariencia a servidores y criados de un nivel económico menor al de otros afines y, por eso, con un menor reflejo documental.

El porqué de estos mecanismos ha de entenderse desde la propia mentalidad de patronazgo de los titulares de la casa. El propio Lope Sánchez, al realizar una donación a Francisco de Reinoso, dice: "Justa e deuida cosa es que aquellos que bien siruen sean rremunerados et los otros el contrario, que syn rrazon es que los bienes ayan de pasar syn galardón e los males syn penna por que así conmo la puniçión o themor de aquella refrena los males así la rremuneración faze cresçer los seruiçios e conseruar muchos ell estado de los grandes, e los faze seer de los suyos amado" Por tanto, la remuneración se revela como un medio más de consolidar la casa. Por un lado, porque vehicula la relación de la casa con los afines dotándolos de medios y, por otro, permite aumentar virtualmente el patrimonio de la casa. Además, este tipo de relación amplía mucho lo que deberíamos entender en la documentación como afín, ya que no es exclusivo de hidalgos y escuderos.

En este sentido, dado lo fragmentario de la documentación, cabe realizar una prevención sobre qué consideramos o no afín a partir de la relación económica. Puesto que se puede constatar la existencia de individuos que se relacionan ocasionalmente con las casas señoriales a este nivel mediante el cobro de rentas, la venta de propiedades señoriales o la usurpación de beneficios ${ }^{90}$. Así, en 1447, Álvaro de Isorna, arzobispo compostelano, amenaza y excomulga a "Afonso Vaasques Abril e Juan Vinagre e Ruy Fernandes do Camiño, canbeadores vezinos d[esta dita] çidade de Santiago por recaudar impuestos sobre labradores e ca[seiros] dos ditos benefiçiados", que están exentos ${ }^{11}$. Podría parecer una mera censura, pero en la misma carta se manda a diez nobles, entre ellos Ruy Sánchez y Rodrigo de Moscoso, que no realicen pedidos en las zonas y personas exentas del arzobispado. Esto implica que el prelado censura a aquellos que realizan los cobros, por excederse en un negocio en el que actúan facilitando la vertiente económica de las diferentes casas que le usurpan señorío, pero sólo uno de los censurados, Alfonso Vázquez Abril, es escudero de Ruy Sánchez; lo que no implica que el resto pertenezcan al entorno señorial.

\section{ENTORNO Y VIOLENCIA SEÑORIAL}

La base física de la relación de interdependencia entre señores y afines estriba en el territorio, en el mantenimiento, administración y explotación del señorío y, fi-

\footnotetext{
algunos datos respectos al nivel de bienes y vasallos de acostamiento de los "principales de la casa" en tiempos del III Conde de Altamira, VA, pp. 211-212.

${ }^{88}$ Vid. Pedro de Zamora.

${ }^{89}$ Sobre la perduración en épocas posteriores de esta concepción, gratificación-punición, de la relación del titular para con el entorno I. ATIENZA, Pater, pp. 417 y ss.

${ }^{90}$ Vid. Alfonso de los Ríos, Gonzalo Rodríguez Porra y Mendo Quinteiro.

${ }^{91}$ ACS, S. 17/ 79. Téngase en cuenta el nivel económico y la capacidad de gestión alcanzada por estos canbeadores, y probablemente sus familiares, ya que podrían hallarse gestionando para varios señores con feudos muy distantes.
} 
nalmente, el servicio armado inmediato ${ }^{92}$. El ejercicio de estas funciones es básico en la identificación del afín con la casa y su vinculación directa a la misma ${ }^{93}$. De los casos anteriores, la documentación aporta mucha información pero, en nuestra opinión, son los conflictos los que revelan claramente el relativo grado de libertad logrado por los afines respecto a los vínculos con la casa, si bien es únicamente una faceta más de la compleja estructura en la que participa el entorno.

Las funciones militares de los afines al servicio de la casa, en sus distintas "campañas", se dibujan como de particular importancia dentro de las relaciones que vinculan al señor y sus criados. Ello resulta particularmente bien significado a partir de diferentes ejemplos documentales. Acaso el más destacado (tanto por su simbolismo como por la implicación de otras casas), sin duda, es el afianzamiento de los Moscoso en torno a la fortaleza de Altamira. En esta fortaleza, edificada por Bernal Yáñez de Moscoso, estaría cautivo Alonso de Fonseca tras ser capturado en marzo de 1465 por Bernal ${ }^{94}$. Altamira fue remodelada después de 1469 , iniciando las nuevas obras el hidalgo García Martíz de Barbeira que, además, aguanta una intentona de asalto a la fortaleza por parte de Luís de Acebedo, hermano del arzobispo. Una vez Lope Sánchez de Moscoso ha consolidado la fortaleza, nombra como alcaide a García Pérez de Costela y envía a su escudero, Lope de Cádavo, a ocupar la fortaleza de Cira, amenazando el señorío arzobispal. Ante esto, las tropas arzobispales inician el asedio de Altamira. En esta situación, Lope Sánchez recurre a la ayuda de otras casas (Andrade, Mariñas, Ulloa y Sotomayor); por su parte García Martíz, con tropas de la zona de Trastámara, intenta socorrer la fortaleza, siendo rechazado en Pontemaceira. Finalmente, la fortaleza no cae y las tropas arzobispales son derrotadas por los nobles ${ }^{95}$. A partir de este ejemplo, en efecto, se evidencia cómo ciertos afines constituyen la fuerza militar, acompañan al titular, participan en las acciones e incluso las dirigen o aconsejan al respecto ${ }^{96}$.

Si observamos con mayor detenimiento la documentación, no parece lógico pensar que, por más peso que la mentalidad de servicio y el honor tuvieran, los afines presten su servicio y sus bienes considerando exclusivamente el beneficio de ciertas acciones para sus señores. Como ejemplo de esto, habríamos de tener en cuenta la

${ }_{92}$ Cabe destacar que el II Conde de Altamira acudió a la toma de Bugía y siendo herido "non consenti que onbre de mi casa se volbiese comigo antes a todos les roge que fuesen adelante con la vendiçion de Dios, los quales fueron los primeros que entraron por la puerta de la çibdad defendiendola los moros". CA, p. 587. Sobre el acompañamiento del conde en otros contextos vid. ACS, p. 001, f. 109 y Fernán López de Navia.

${ }_{93}$ Así habríamos de entender la curiosa alusión a los afines del Conde de Altamira en AHDS, Fondo General, Catálogos, no 2, f.15v: "Çiertos autos que pasaron en la cuidad (sic) de Santiago en el pleyto que trataba el arçobispo de Santiago y su cabildo con el conde de Altamira y sus litis consortes sobre la jurisdicción de la iglesia". Por otro, la relación de los afines para con la casa (y entre casas) se ve en la comunicación de Vasco López, "escudeiro, juyz enna abdiençia da Ponte da Varzea...por Gomes Peres das Mariñas, que pone en conocimiento del Muy honrrado caualeiro et sennor Roy Sanches de Moscoso, vasalo de noso sennor, et Gil de Trilos, [... . ]vezo Ameyrín et Lopo de Carra voso moordomo" una sentencia para que la haga cumplir, vid. ARCHV, Pleitos Civiles, La Puerta (olv.), caja 232, exp. 2, f. 73r. Como también se ve en las quejas del convento de Belvís contra "el Conde d'Altamira conmo sus escuderos e criados e apaniaguados", AGS, Registro General del Sello, 1486, 10, f. 42.

${ }^{94}$ Que "entró con gentes de armas de cavallo e de pie en la dicha villa de Noya e en la casa arçobispal, donde el dicho Arçobispo estaba", E. PARDO, Los señores, vol. II, pp. 167, J. GARCÍA, y M. J. PORTELA, Los Fonseca, pp. 219 y 225 y AHDS, Fondo General, Catálogos, no 2, f. 8r.

${ }_{95}$ VA, pp. 181-187 y 227-228.

${ }^{96}$ Como Fernán Álvarez de Carantoña, "que era hombre de gran seso y pocos havía de más consejo", ibidem, p. 180. 
relación de afinidad que el propio Ruy Sánchez de Moscoso tiene con Fadrique, duque de Arjona, y que tanto ayudaría a la expansión de los Moscoso al norte del Tambre ${ }^{97}$. Esta relación llega a implicar el enfrentamiento directo, en 1424, con la sede compostelana de Ruy Sánchez "e de sus secaçes" ${ }^{98}$. Por otro lado, la implicación del afín puede derivar de la cercanía de sus intereses territoriales al destino de una casa, ya sea porque su sustento depende de la misma o porque se espere un engrandecimiento propio, mediante el ejercicio de cargos o la munificencia señorial. Aún así, la participación del entorno en los conflictos señoriales también se revela como forma de limitar su escalada como en el caso del ataque a Corcubión pues los participantes en el ataque proceden de áreas en las que la casa de Moscoso no capta afines ${ }^{99}$.

Tengamos presente que el entorno de los Moscoso se podía ver envuelto en graves problemas en el transcurso de su servicio. Caso de unos criados del conde que intentan llevarse a un peón que había asesinado a uno de los servidores de la casa y acaban encarcelados por el alcalde mayor del arzobispo en la torre da praza en Santiago, hasta que "Súpolo el conde, y escribiole tan áspero al alcayde con tantas amenaças que luego los solto sanos y sin lesión" 100 .

Por ello, el enfrentamiento bélico se revela como una opción tremendamente meditada por la casa ${ }^{101}$. Pensemos en el ejemplo de Vasco Fariña de Lamas, alcaide de la fortaleza de Xallas, que, junto al conde de Altamira, el obispo de Tui y Suero Gómez de Sotomayor, es reprendido por el rey Fernando, en $1476^{102}$. O el caso del expeditivo mayordomo Ferrando Peres, que parece extralimitarse en su celo administrativo ${ }^{103}$. Aunque, en estos contextos tardíos, no parece que la fuerza de los Moscoso pudiera paliar las consecuencias para los suyos de usurpar una fortaleza arzobispal o cobrar derechos señoriales a hidalgos ${ }^{104}$.

\footnotetext{
${ }^{97}$ Ruy recibió en 1411 las fortalezas de Vimianzo y Broño, que luego por matrimonio se incorporarían definitivamente a su casa, y también acompañó a Fadrique a Castilla, vid. E. PARDO, Los señores, vol. I, pp. 265-266 y 287. Diferimos con X. REI y A. M. FrAMIÑÁN, As terras, pp.190-192 en creer que Ruy tuviera una clara posición de fuerza en la zona antes de su relación con el de Arjona.

98 AHUS, Colección Blanco Cicerón, Pergaminos, n ${ }^{\text {o } 36 . ~ U n ~ c a s o ~ s i m i l a r ~ s e r i ́ a ~ l a ~ c o l a b o r a c i o ́ n ~ d e ~}$ Bernal Yáñez de Moscoso con la casa de Andrade en contra de Gómez Pérez das Mariñas, E. PARDO, Los señores, vol. II, pp. 121-123.

${ }^{99}$ En concreto el arzobispo moviliza gentes de Padrón, Fefiñaes, Vilanova de Arousa y O Grove. Algo que explica la llamativa ausencia de gentes de Noia o Muros pues la casa tiene relaciones durante todo el XV y podría resultar contraproducente la participación en el bando arzobispal de afines que se situaban a caballo entre ambas lealtades.

${ }^{100}$ Hay otro caso similar en tiempos de Ruy Sánchez, VA, pp. 176 y 200-201. Aunque en ambos casos la disputa deriva de la tensión jurisdiccional con el arzobispado, pues el enfrentamiento se centra en atacar a los agentes del entorno cuando ejercen justicia.

${ }^{101}$ M. HiCKS, Bastard, pp. 389-394.

${ }^{102}$ Siendo amenazado con "caher en mal caso e en aquellas penas en que cahen y yncurren los que a sabiendas contra los mandamientos de su rrey y señor tienen las fortalesas de sus rreynos", AGS, Registro General del Sello, 1476, 3, f. 141. Por lo que tal vez podría plantearse que lo que indica el documento es una negativa a restituir la fortaleza al arzobispo compostelano, cambiando así de casa (vid. apéndice). Sobre el marco legal de la tenencia de fortalezas, M. C. QUINTANILLA, La tenencia, pp. 865-868.

${ }^{103}$ AGS, Registro General del Sello, 1495, 2, f. 490. Ante la negativa del hidalgo Alvar Gómez a llevar unas cargas de carbón, el mayordomo "echó mano a la espada que traya, e desnuda de la vaya, diz que dio a su muger con ella ençima de la cabeça vn golpe que... diz que dio con ella en terra, e trayda a sus pies le dio otros muchos golpes llamandola puta vellaca, diziendole otras palabras ynjuriosas". Finalmente, el mayordomo volvería a maltratar a la mujer e hijo del hidalgo y a cobrarle rescate por varios bueyes.

104 "por todos los que por él fiçieron pagó por ellos todas sus querellas, asta vender toda la plata y traer bajilla de barro por remediar a todos sus criados", VA, p. 199.
} 
No obstante, esta necesaria relación titular-afines es consustancial a la casa. Desde mayo de 1411, se da un enfrentamiento armado entre los escuderos Ruy Sánchez de Moscoso y García Díaz de Mesía por la posesión de ciertas tierras y heredades que habían quedado de Constanza de Moscoso, hija de Lope Pérez de Moscoso. Las partes recurren a la intervención del arzobispo como árbitro en el mes de agosto ${ }^{105}$. No obstante, su sentencia no debió resultar satisfactoria para los implicados prolongándose el enfrentamiento armado ${ }^{106}$. Finalmente, cada parte elige tres escuderos que actuarán como "amigaueles árbitros" en el debate; la sentencia será dada ante otros siete escuderos afines a las partes ${ }^{107}$. Tal vez, la amplia participación de este entorno, tanto en el enfrentamiento como en su resolución, fue lo que le dio verdaderamente una mayor solidez respecto al primer intento de arbitraje. De hecho, en 1470, tenemos un arbitraje similar entre Sancho de Ulloa y Lope Sánchez en el que se implica al conde de Lemos, representado por un afín, y en el que cada parte nombra a sus hidalgos ${ }^{108}$.

Pero, a la inversa, la relación de los afines para con el titular de la casa se revela también como una herramienta útil de control social de la violencia dado que, en cierta medida, las acciones de los dependientes han de ser controladas por la casa y su titular como responsable último. Así, en 1459 el concejo de A Coruña pretende recurrir al conde de Trastámara para que pida a Bernal Yáñez de Moscoso que indague un suceso atribuido a "los omes suyos que se sospecha de ser de sus casas \dellos/ e non de otra parte"109. Una limitación similar al papel jugado, a una escala superior, por los Moscoso en los enfrentamientos entre otras casas emparentadas ${ }^{110}$.

Podríamos preguntarnos cómo actúan los afines en caso de que el conflicto no implique únicamente a su casa, sino a la nobleza como grupo social. En este sentido, en un acuerdo, en agosto de 1482, entre varios nobles de importancia para proteger la validez de sus encomiendas ante los reyes, los nobles deciden nombrar una serie de jueces, que velarán porque no haya excesos. Uno de los dos caballeros elegidos para el arzobispado de Santiago será Fernán Álvarez de Carantoña, cuya relación con los Moscoso, en estas fechas, está atestiguada y que en ningún momento es mencionado como afín, criado, vasallo o escudero de la casa de Moscoso. Lo cual resultaría extraño de no ser porque, en el mismo momento, prestan homenaje otros muchos caballeros sin mencionar su relación para con otros señores y casas. De éstos, hay varios que

${ }^{105}$ AHUS, Clero, Mitra, leg. 133, pieza 8, una copia del mismo en ASPA, Condado de Altamira, 6F3/ 717. Vid. VA, p. 161 y CA, pp. 505 y 520. El conflicto en todo caso podía venir ya de varios años antes, vid. AHDS, Fondo General, Catálogos, n 2, ff. 59v-60r y 70r.

106 "sobre las prendas que foron tomadas entre nos...et sobre los omes que cada hun de nos ten enna terra do outro, et sobre los erros e queixumes [roto] dentre nós e nosos escudeiros e omes que cada hun de nós ten enna terra do outro" AHUS, Clero, Mitra, 133, pieza s/n.

${ }^{107}$ Los jueces de la parte de Moscoso son los escuderos Martín Lourenço, Pedro Soneira y Gil Rodrigues. Los escuderos de Ruy Sánchez que atestiguan el proceso son Johan Corujo, Gonzalo Beserra do Val de Veyga, Fernán Gonzales y Álvaro Sánchez.

${ }_{108}$ ACS, LD 9, 2, f. 10v. Por la parte de Moscoso: García de Barbeira, Vasco Prego, Jerónimo Sánchez de Lojo y García Pérez de Costela. El enfrentamiento derivaba de la herencia de Lope Sánchez de Ulloa.

${ }^{109}$ A. M. FrAmiÑán y A. PRESEdo, Estructuras de parentesco, p. 120 (n. 55) y Dolores BARRAL, La Coruña en los siglos XIII al XV, A Coruña, 1998, pp. 419-420. La carta para Bernal diría, más explícitamente, "mucho vos rogamos que con voluntad mandedes saber en vuesta casa como a Vuestra Merçed mejor visto fuere". Para un caso similar relacionado con Urraca de Moscoso en 1480, vid. Álvaro de Riballano.

${ }^{110}$ Como sucede en el enfrentamiento entre Diego de Muros y Pedro Álvarez de Sotomayor y también en la concordia de 1474 entre el Arzobispo y Pedro Álvarez de Sotomayor, llegándose a plantear que el "visconde de Finesterras" quede al cargo de la villa de Pontevedra como garantía. CA, pp. 45-46 y J. GARCía y M. J. PORTELA, Los Fonseca, pp. 293-295. 
también se relacionan directamente con la casa: Álvaro de Rendal, Lope de Cádavo, Gómez de Ventosa, Martín de Reino y Francisco de Reinoso ${ }^{111}$.

Por todo ello, al acercarnos a los pormenores de estos vínculos de carácter militar, podemos apreciar cómo, en buena medida, la participación de esos escudeiros y fidalgos que apoyan a los Moscoso cuenta con una faceta poco valorada, como es la capacidad de esta relación para limitar los conflictos, tanto los derivados de la competencia interseñorial, de una casa con otra, como los generados en el seno de la propia casa. Algo que deriva de la confluencia en este marco de relaciones verticales y de relaciones horizontales.

\section{RECAPITULACIÓN}

Los aspectos brevemente tratados aquí requerirían una aproximación más específica, a través de una indagación documental más amplia. Por otro lado, en esta primera aproximación al entorno de la casa de Moscoso se ve cómo los afines articulan el funcionamiento real del señorío, avanzando datos que permitirían emplear otras metodologías, tal vez más de moda actualmente, como el estudio antroponímico en conjunción con el análisis espacial, o un análisis de la topografía del poder que tenga en cuenta tanto el asentamiento físico del poder como la distribución simbólica del mismo.

En nuestra opinión, parte de los que serían los afines a los Moscoso, en origen, comienza apoyando a un igual, a una familia de caballeros de condición muy similar a la suya, que destaca por su liderazgo o habilidad política y que les reporta beneficios concretos derivados de la labor de patronazgo de los sucesivos titulares. El resto de los individuos del entorno, sin ser hidalgos, sirve a la casa por su sustento y futuro, por tradición familiar de ese servicio y también por la retribución económica y social del mismo. Esa confusión ocasional en el registro escrito de los términos para referirse a todos ellos proviene, precisamente, de su relación con el titular.

El éxito de las estrategias desplegadas a largo plazo por los Moscoso -lo que acaba por consolidarlos frente a otros señores como importantes magnates en el reino de Galicia- parte de esa capacidad para construir una red de clientes sólida, con una cierta transversalidad social ${ }^{112}$, a su servicio, fidelizando a sus afines. En este proceso, tendríamos que contextualizar adecuadamente la evolución de la casa en relación con los cambios del panorama señorial en la Galicia del XV (como, por ejemplo, el auge y caída de Fadrique, duque de Arjona), tanto política como territorialmente.

Esta situación, de fijación de un entorno afín, comienza a cristalizar tras la formación de un señorío estable, refrendado por la intitulación de Conde de Altamira de Lope Sánchez de Moscoso ${ }^{113}$. Así, posteriormente, estos éxitos dan lugar a que

${ }^{111}$ CA, pp. 564-570. Algunos firman como testigos vecinos de Santiago.

${ }^{112}$ M. HiCKS, Bastard, p. 389 (n.7).

${ }^{113}$ Pese a los intentos bélicos de Bernal Yáñez este título aparece a partir de 1475 como concesión regia, por otro lado Lope Sánchez de Moscoso llegaría a intitularse brevemente Vizconde de Finisterre. Vid. ACS, S. 17/ 22, AHDS, Fondo General, Bienes y Rentas de la Mitra, 28, ff. 126/144, ASPA, Condado de Altamira, 6A/ 463, AGS, Patronato Real, leg. 59, doc. 27, ff. 109r-112v, A. M. FRAMIÑÁN, $O$ título vizcondal de Fisterra no contexto da creación de títulos en Galiza na Idade Media, "Estudios de genealogía, heráldica y nobiliaria de Galicia", 3 (2004), pp. 427-431 y J. GARCÍA y M. J. PORTELA, Los Fonseca, p. 298. En AHDS, Fondo General, Bienes y Rentas de la Mitra, Catálogos, $\mathrm{n}^{\circ}$ 2, f. $25 \mathrm{r}$ se menciona "vna carta e prouysión de los reyes catholicos en papel firmada de su nombre e sellada con su sello para Lope Sánchez de Moscoso que dexase la villa de Finysterra y no se yntitulase de vizconde della porque hera de la iglesia de Santiago, dada en Olmedo a seys 
los principales servidores de la casa vean satisfechas sus expectativas de promoción social al acceder al ejercicio de oficios señoriales relevantes (mayordomos, jueces, merinos, alcaides y, especialmente, alcalde mayor, cargo este último, asociado directamente a la identificación del señorío de la casa como territorio vinculado a un título condal y a un mayorazgo) e incluso, a la adquisición de fortalezas de manos de sus señores; ya no como meros alcaides o merinos sino como pequeños señores per se, lo que sucede con Costela y Barbeira.

La capacidad de estos afines para engrandecer la casa con sus bienes, con su servicio armado y con sus propias vidas y, por tanto, la fundamental relevancia de estas relaciones personales para el sostenimiento y encumbramiento de una casa noble, es lo que explica plenamente una manda testamentaria de Lope Sánchez de Moscoso: "Yten dejo encomendados al dicho don Rodrigo de Moscoso, mi heredero, todos mis escuderos y criados y de mis antecesores y suios para que los aya a cargo y les faga honra y merced por quanto por mis antecesores y por mi sufrieron muchos travajos y afruentas" 114 .

APÉNDICE: AfINES DE LA CASA DE MOSCOSO ${ }^{115}$

\section{Ruy Sánchez de Moscoso (m.1456)}

-[...]vezo Ameyrín juez y merino ${ }^{116}$

$-[\ldots]$ da Costa escudero ${ }^{117}$

-Afonso Lopes escudero, criado y justicia ${ }^{118}$

días de março de MCCCCLXXV annos". Ya en su momento K. B. MCFARLAne, Bastard, p. 38, destacaba la importancia de la fama y las expectativas respecto al titular para el establecimiento de relaciones de servicio.

${ }^{114}$ CA, p. 123.

${ }^{115}$ Para la elaboración de la nómina nos hemos guiado por varios criterios que nos permitan establecer, con cierto grado de fiabilidad, que existe una relación de afinidad con los diferentes titulares de la casa. No obstante, resulta más complicado intentar fijar la cronología de la misma, por lo que optamos por guiarnos por los cambios de titularidad. La relación de afinidad debe ser explícitamente aludida en la documentación dimanada de la casa, en caso de no serlo un individuo debe aparecer repetidamente en la documentación referida a los Moscoso (sea bajo diferentes titulares o en relación a sus familiares) o que, al referir a sus descendientes, se le mencione. Si se relaciona a un individuo como criado de un familiar (como Juana de Castro o Urraca de Moscoso), entendemos que existe también relación para con el titular. En el caso de los individuos mencionados en el libro de acostamientos de 1510 optamos por incluir únicamente aquellos en los que se especifica que mantienen su cargo o los beneficios que tenían del II conde de Altamira; respecto a los nombres relacionados con el aprovechamiento de los beneficios de la casa (c. 1528), sólo nos sirven de apoyo, pues no indican cronologías, además de poder incluir individuos ya fallecidos en el momento de su redacción. Indicamos titular, nombre del afín y la denominación normalizada que aparece en la documentación. A su vez, van entre corchetes: aquellos individuos cuya relación con los titulares es dudosa pero posible, variantes del nombre de un determinado personaje o lecturas documentales poco claras. Se indica con un interrogante los casos en que no hallamos términos que definan el oficio o servicio desarrollado por el individuo. En caso de que un individuo aparezca al servicio de varios titulares se especifica esta situación. En nota al pie van las referencias documentales a los personajes listados y las referencias prosopográficas relativas a cada individuo y su familia.

116 Nota 93.

${ }^{117}$ Testigo en la lectura en Guldrís del testamento de 1456.

${ }^{118}$ Urraca de Moscoso lo refiere como tal en un interrogatorio sobre el origen de sus derechos en las tierras de Ferreirós, Montaos y Chaos de Labacolla que reclama Alonso de Fonseca II, CA, p. 265. 


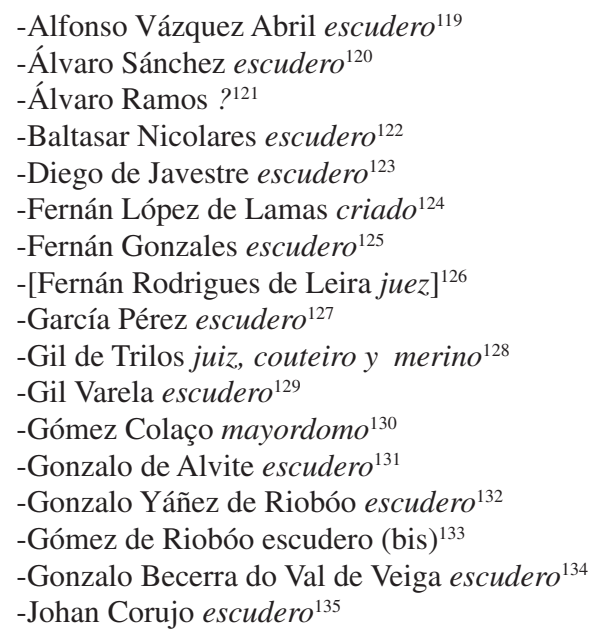

${ }^{119}$ Con el titular como testigo en 1438 en Noia, F. BouZA, El señorío de Villagarcía, pp. 98-99 y nota 91.

${ }^{120}$ Aparece en 1412 como parte de Ruy Sánchez, AHUS, Clero, Mitra, 133, pieza s/n.

${ }^{121}$ Hay referencia de que Juana de Castro le mandó que tuviese la fortaleza de Vimianzo por "Ruy Sanches e le quitaba qualquier pleito omenaje que el oviese hecho al Duque don Fadrique"; por lo que su incorporación al entorno derivó del entronque matrimonial de Juana con Rodrigo de Moscoso, CA, p. 481. Pese a que procedía probablemente del entorno de Fadrique, Ruy Sánchez había tenido las fortalezas de Vimianzo y Broño antes de la alianza matrimonial y, por tanto, del establecimiento de la dote de Juana.

${ }^{122}$ Presente como testigo del testamento de 31 de julio de 1456 en el Pazo de Guldrís.

${ }^{123}$ Vid. Alfonso Vázquez Abril

${ }^{124}$ En los contratos firmados en Noia por Ruy Sánchez para su matrimonio con María Rodríguez de Caamaño, F. BouZA, El señorío de Villagarcía, pp. 96-99, es mencionado como criado, recibiendo una importante dote consistente en varias feligresías que había poseído la abuela de Ruy Fernández de Caamaño. Era hijo de Lopo de Coscones de Lamas, ya fallecido en 1438, por lo que probablemente su padre había servido a Ruy Sánchez y había encomendado a su hijo. El servicio a la casa de los Lema pudo continuar en la figura de Gonzalo López de Lamas y Fernán López de Coscones.

${ }^{125}$ Vid. Álvaro Sánchez.

${ }^{126}$ Es referido junto a Vasco Martínez para ayudar a los cumplidores del testamento pero se añade que "nono podendo aver que tomen consigo en seu lugar algun outro meu criado", CA, p. 94.

${ }^{127}$ Está presente en una indagación, presidida por el titular, relativa a unas heredades de Ruy Sánchez y a sus rentas AHUS, mic. 35 [ADM, Cillobre, leg. 5, nº 21].

${ }^{128}$ Vid. [...]vezo Ameyrín.

${ }^{129}$ Vid. [...] da Costa, Baltasar Nicolares y, como Gil Rodríguez Varela, Alfonso Vázquez Abril.

${ }^{130}$ Aparece como recaudador de unos "labradores do dito Roy Sanches" Vid. García Pérez.

${ }^{131}$ Ibidem.

${ }^{132}$ Vid. [...] da Costa.

${ }^{133}$ Marido de Berenguela López, sobrina de Ruy Sánchez, murió en Corcubión al servicio del siguiente titular en 1457, CA, pp. 95 y 539. En el acta de lectura del testamento de 1456 figura como Álvaro Gómez de Riobóo.

${ }^{134}$ Vid. Álvaro Sánchez. Sobre los Becerra vid. nota 28. Gonzalo era hijo de Martín Becerra de Cances, padre del propio Ruy Sánchez de Moscoso. Vid. la pervivencia y memoria de propiedades de Martín Becerra de Cances en la casa de Moscoso en AHUS, Clero, legs. 826, f. 184.

135 Ibidem. 


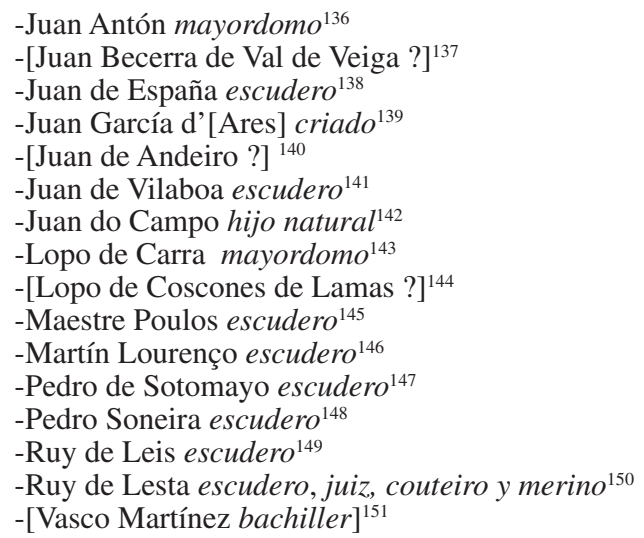

\section{Rodrigo de Moscoso (m. 1458)}

-[Juan de Andeiro ?]

-[Fernán de Betanzos escudero $]^{152}$

-Fernán de Lema de Muxía escudero ${ }^{153}$

-Gil de Brión mayordomo ${ }^{154}$

\footnotetext{
${ }^{136}$ Este nombre aparece mencionado, ya muerto el titular, en una declaración respecto a unas propiedades de la familia Moscoso, CA, p. 212.

${ }^{137}$ En la dote de Juana de Castro de 1425 aparece como testigo aunque podría ser un pariente relacionado con el entorno de Fadrique, duque de Arjona y conde de Trastámara, CA, p. 526.

${ }^{138}$ Vid. Alfonso Vázquez Abril.

${ }^{139}$ Vid. [...] da Costa.

${ }^{140}$ VA, pp. 143,155 y 173, lo relaciona con la casa tras un cambio de lealtad "desque se despidió de Gómez Pérez"m acabando después en la de Andrade "desque se trató mal con el conde de Altamira", por lo que su servicio a la casa puede prolongarse hasta él.

${ }^{141}$ Vid. [...] da Costa.

${ }^{142}$ CA, p. 95, aunque el testamento de 1456 le lega varios bienes mencionando que era cura en S. Salvador de Sofao.

${ }^{143}$ Vid. [...]vezo Ameyrín.

${ }^{144}$ Vid. Fernán López de Lamas.

${ }^{145}$ Vid. Baltasar Nicolares.

146 Vid. Álvaro Sánchez.

${ }^{147}$ Vid. Baltasar Nicolares.

${ }^{148}$ Nombrado árbitro en 1412 junto a un tal Gil Rodríguez que sería de la parte de García Díaz de Mesía, vid. Álvaro Sánchez y Diego de Leis.

${ }^{149}$ Vid. García Pérez.

${ }^{150}$ Vid. [...] da Costa. Luna.

${ }^{151}$ Vid. Fernando Rodríguez. En 1449 era clérigo y juez en la audiencia arzobispal de Rodrigo de

${ }^{152}$ Esta entre los testigos de la carta de Lope Pérez de Moscoso de 1457 junto a Martín Romeu, vid. infra.

${ }^{153}$ Mencionado específicamente como escudero de Rodrigo de Moscoso en 1448, AHUS, Clero, Mitra, leg. 133, pieza 16 (Editado en CA, pp. 526-529).

${ }^{154}$ En diciembre de 1456, al poco de la muerte de Ruy Sánchez, se le menciona en la pesquisa sobre las propiedades que quedaban de tiempos de Bernal Yáñez do Campo CA, pp. 199 y 211.
} 


\author{
-Gómez de Riobóo criado (bis) \\ -[Gonzalo Barba de Figueiroa escudero] ${ }^{155}$ \\ -Juan García Daaro criado y familiar ${ }^{156}$ \\ -[Juan García de Barbeito escudero] ${ }^{157}$ \\ -Juan Rodrigues de Campaño ?158 \\ -Lope Pérez de Moscoso o Mesía ? ${ }^{159}$ (bis) \\ -Martín Romeu criado (bis) ${ }^{160}$ \\ -Pedro de Neveiro escudero ${ }^{161}$
}

\title{
Bernal Yáñez de Moscoso (m. 1466)
}

-Aparicio Borrallo deuda ${ }^{162}$

155 Vid. Fernán de Betanzos. Si bien, en 1540 hay referencia de un alcaide de Altamira con el mismo nombre, ARCHV, Pleitos Civiles, La Puerta (Olv), Caja 795, exp.2, ff. XXXVIr-XXVII.

${ }^{156}$ Atestigua la presentación de la negativa de Rodrigo de Moscoso y los caballeros para ir a la guerra, ACS, LD 19 / 13, f. 12v.

${ }^{157}$ Vid. Fernán de Betanzos.

${ }^{158}$ El testamento de Álvaro Pérez indica que "Yten mando máys, a Juan Rodrigues de Canpanno, porque lle so obligado e por servycio que fezo a meus padres, e abço o jur de presentar que eu ey enna ygllesia de Santa María de Leyra".

${ }^{159}$ Sobre su relación con Rodrigo vid. Martín Romeu. La relación con Bernal Yáñez se deriva de una deuda entre ambos mencionada en el testamento de su hermano "Yten, mando a mev conpridor que demande a Lopo Peres de Mesya noventa mill pares de blancas de que hera obligado, e eu cargo, ao dito mev yrmano Vernaldo Eanes". Si bien cabe destacar que, en la negativa a acudir con el arzobispo a la guerra en 1458, su escudero Gonzalo Fraguio acompañó a Pedro de Neveiro, escudero de Rodrigo de Moscoso lo que evidencia que su relación de afininidad para con la casa debió iniciarse por su entronque matrimonial con la casa; por ello, siendo segura su afinidad con Álvaro Pérez, hemos de remotarla a Rodrigo y a Bernal.

${ }^{160}$ Hay un posible familiar Fernán Romeu, mencionado en 1451 en una toma de posesión por parte de un Sotomayor, A. RODRÍGUEZ, Documentación, p. 422, y que, en torno a 1457, era escudero de Lope Pérez de Moscoso apareciendo junto a él en una escritura "feyta ennos paaços de Folgoso que son de Rodrigo de Moscoso" y es atestiguada por el propio Martín como criado de Rodrigo, AHDS, Jurisdiccional, 11, cuaderno $3^{\circ}$, ff.53v-55r/89v-90r. En 1516 Martín Romeu, es reprendido por Diego Hurtado de Mendoza como alcalde mayor del condado junto a los tenentes de Altamira, Vimianzo y Cira (ACS, S15/53). Al año siguiente, hubo de sufrir en Santiago un asalto en las casas de la Praza do Campo perpetrado por agentes arzobispales en el que se sustrajo documentación condal; la excusa para el mismo fue el ejercicio judicial en la zona de San Marcos, técnicamente parte de la ciudad. Su hijo Juan Romeu estaba en estos momentos también al servicio de la casa, su hija, Urraca de Moscoso, testificó también respecto al abuso recibido, César OliveIRA, La Galicia de Vasco de Aponte: los pleitos del arzobispo Tabera contra los linajes de la Tierra de Santiago, "EM", 22 (1999), pp. 300-301, el documento en AGS, Cámara de Castilla, Personas, leg. 120, doc. 134 (editado en CA, pp. 625-651). Agradecemos a V. Muñóz el cedernos sus referencias de este documento. Sobre una querella que llevó, junto a Gómez de Ventosa, contra otro afín, Ruy Tato, en torno a unas propiedades en Ponte Ledesma, vid. CA, pp. 286-288.

${ }^{161}$ Sobre su relación con Montaos vid. ACS, LD. 29 / 10, donde firman como testigos varios "homeees de Pedro Vermues de Montaos", y sobre la negativa al llamamiento arzobispal ACS, LD 19/ 13, ff. 2-5r, documento bastante conocido por su relación con una negativa similar en 1369, durante el arzobispado de Rodrigo de Moscoso, vid. Xosé Manuel SÁncHEZ, A Colección López Ferreiro do Arquivo-Biblioteca da Catedral de Santiago de Compostela, Vigo, 2008, p. 96. Un posible familiar sería el prior claustral de S. Martiño, Lopo de Niveiro, M. LUCAS, El archivo, p. 212.

162 Tenía una prestanza de por vida con Suero de Marzoa, que habría de ser pagada por el heredero del Conde de Altamira a cargo de las deudas que con Borrallo tenía la casa desde tiempos de Bernal Yáñez. Aparece atestiguando la lectura del testamento condal de 1500 y, como notario, su copia en 1504. El pago a Suero de Marzoa probablemente salió de la merindad de Montaos. CA, pp. 118, 127, 131 y 448 (n. 305). 


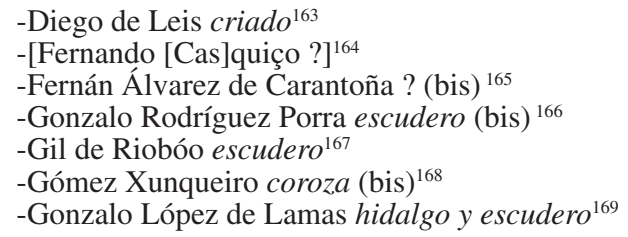

${ }^{163}$ Vid. Juan Prego. Hay otros individuos con este mismo apellido, que bien pudiera estar emparentado, al servicio de otros titulares, al de Lope Sánchez de Moscoso tenemos a García, Lopo, Martín, Rodrigo, Gonzalo de Pazos, y a Vasco. Nótese que el padre de Gonzalo de Pazos, Rui Sonera (que podría ser afín de los Sotomayor o del arzobispado pues aparece atestiguando un acuerdo entre ambos en 1460 en la fortaleza de Rocha Forte, ACS, IG 709 / 4, f. 52v, por lo que no nos atrevemos a asignarlo como afín de los Moscoso, puesto que no podemos precisar cuándo lo fue, siendo mencionado uno con el mismo nombre en el listado de beneficios de c. 1528, CA, p. 447), podría tener, a su vez, alguna relación con Pedro Soneira, escudero de Ruy Sánchez. Lopo de Leis (Leys o Leyes), tiene un pleito con San Paio de Antealtares por una posesión en AHUS, Colección Blanco Cicerón, Pergaminos, $\mathrm{n}^{\circ}$ 64. Aparece también un Lopo de Leyes, vecino de Cee, en una procuración del concello en 1498, sin que podamos precisar si se trata del mismo individuo, vid. AHDS, Fondo General, Bienes y Rentas de la Mitra, 28, ff.115/12-116r/13r. Tras la muerte de Rodrigo Osorio de Moscoso aparecen Lopo, Martín y Ruy de Leys.

${ }^{164}$ Emparentado con Martín de Leis y vecino de la zona de Cee, X. REI y A. M. FrAmiÑÁN, As terras, pp. 211-215. Aparece en una igualación de 1456 entre varios arrendadores de rentas sin expresar filiación, lo hallamos también en un albalá de Bernal Yáñez en 1461, AHDS, Fondo General, Bienes y rentas de la Mitra, 28, ff. 77 y 85. Su afinidad parece clara en tiempos de Lope Sánchez pues es mencionado junto a Martín de Leis y otros en 1486, Vid. Alfonso Gómez de Vilar de Francos.

${ }^{165}$ Aparte del protagonismo que logra en el relato de Aponte, en 1478 fue alcaide de Altamira, cuando se da como seguridad tal fortaleza (si bien aparece como testigo en Noia en 1474 junto a Juan Rodríguez Moula en una donación del titular a otro afín, vid. Juan Vázquez); en 1479 de Vimianzo para garantizar un acuerdo matrimonial con el conde de Benavente; en 1480 aparece entre los testigos del homenaje por Altamira. Mencionado posiblemente en 1486 (vid. Alfonso Gómez de Vilar de Francos). Lope Sánchez, en su última voluntad, atestigua que cambió con él una presentación que le había dado Bernal Yáñez para él y sus hijos, Sancho López y Fernando. Tras la muerte del primer conde llevó las rentas de Corcubión, Nemancos y Mens. M. J. VÁZQUEZ, Los condes, pp. 245-246, 248-250, 255, 265 y CA, pp. 115, 494, 597. En algún momento realizó un traspaso con el conde de propiedades en Salgueiros.

${ }^{166}$ La trayectoria de este personaje resulta llamativa por su vinculación con el cobro de rentas para la casa en el litoral coruñés. Así, en 1459 es mencionado como escudero en una protestación junto a otros escuderos de Bernal Yáñez, ACS, IG 703 / 27, f. 283r, pero en ese año se le menciona como arrendador principal de las alcabalas de Malpica en relación al tesorero de la casa de la moneda de A Coruña, AHDS, Fondo General, Bienes y rentas de la Mitra, 28, f. s.n. (vid. la reflexión sobre el papel de la pequeña hidalguía en la recaudación en el arzobispado en M. VÁZQUEZ, El arzobispo, p. 122 ). Y, en pleno período irmandiño, aparece en la protestación por el cobro de los impuestos de Muxía de 14661467; rentas de las que Álvaro Pérez se había apropiado suplantando los derechos arzobispales, por lo que probablemente seguía funcionando como afín de los Moscoso puesto que poco después acepta haberlas recibido, Anselmo LóPEZ, Os irmandiños. Textos, documentos e bibliografía, Vigo, 1992, p. 102 y AHDS, Fondo General, Bienes y Rentas de la Mitra, 28, ff. 86 y 73/88. Su afinidad con la casa queda clara pues es nombrado también por Lope Sánchez como "curador" de sus bienes en 1469; cinco años más tarde recauda y entrega las alcabalas de Muxía al alcaide de Vimianzo, en la carta de pago del conde de Altamira se le refiere nuevamente como escudero junto a Gómez da Barcia. CA, p. 546.

${ }^{167}$ Afín ya en 1459, ACS, IG 703 / 27, f. 283r; en c. 1466-1467 en virtud de un poder, de Urraca de Moscoso, CA, p. 242, sobre el impago de unas rentas y la necesidad de una carta de los "mayordomos y alcaldes de hermandade". Relacionado con la merindad de Vimianzo en el listado de beneficios, CA, p. 447.

${ }^{168}$ Como tal en el período de Bernal y Álvaro Pérez lo identifica A. M. Framiñán, Notas, p. 347.

${ }^{169}$ En 1459 aparece junto al escudero Gil de Riobóo y a Johan Conlaço pero, en el mismo, recibe el homenaje de Bernal Yáñez. También aparece recibiendo pleito-homenaje de Bernal Yáñez como promesa de cumplir los acuerdos en la igualación con el arzobispo. 


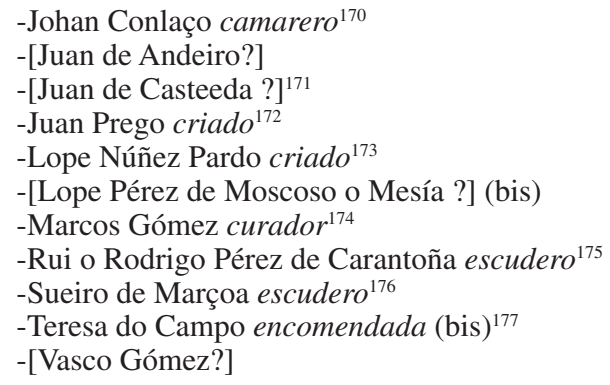

\section{Álvaro Pérez de Moscoso (m. 1467)}

-[Fernando de Castro pariente y deuda] $]^{178}$

-[Gonzalo López de Riobóo?] (bis) ${ }^{179}$

-[Juan de Andeiro?]

-Alfonso de Lesta escudero (bis) ${ }^{180}$

-Alfonso do Río pariente ${ }^{181}$

${ }^{170}$ Único mencionado de esta manera en tiempos de Bernal, Vid. Gil de Riobóo.

${ }^{171}$ Incluimos a éste y a Vasco Gómez como afines de Bernal Yáñez pues aparecen mencionados por Juana de Castro, en 1459, en el cobro de los impuestos de Vimianzo, dando la impresión de que ejercían como mayordomos o merinos en la zona, ASPA, Condado de Altamira, 3A1/ 86, f. 2.

172 Juan Melgarejo, chantre de la catedral compostelana, realiza unas declaraciones un tanto peculiares sobre el de Moscoso y menciona como fuente de sus comentarios maliciosos a Prego, antiguo criado de Bernal Yáñez, y a otros criados como Jacome Pensado y Diego de Leis, TF, p. 290.

${ }^{173}$ VA, p. 15.

${ }^{174}$ Vecino de la villa de Cee, lo asignamos como afín puesto que, por ser menor de 25 años, Bernal le nombró curador en unos pleitos con Mayor de Sotomayor, viuda de Ruy Sánchez de Moscoso, y Pedro Pardo de Betanzos, ACS, IG 703 / 27, ff. 130-131r.

${ }^{175}$ Como testigo en Santiago (octubre de 1459), junto a Bernal Yáñez, ACS, IG 703 / 27, f. 283 r. En su testamento de 1496, APDP, Fondo Especial 1-Familia Caamaño, 1240/ 10, cuaderno suelto, ff. 1-2 (copias en, ibidem. ff. 7v-9, ff. 2v-4 y ff. 2r-3), indica que "Item mando a mi fijo Pedro de Calo... todas las heredades e frutos que yo he e tengo en el coto d'Entines..segund que todo me lo [mandó] el sennor Vernal de Yanes de Moscoso, que santa gloria aya, mi sennor".

${ }^{176}$ Aparece junto a Gil de Riobóo en 1459.

${ }^{177}$ El testamento de Lope Sánchez indica que había sido ya encomendada a Bernal Yáñez como heredero de Juan do Campo. Además, se la doto para casamiento "aun dos veces" siendo criada por el conde y una vez casada "por servicio que nos fizo", CA, pp. 115.

${ }^{178}$ Su relación no es clara aunque debía dinero al fallecido Juan do Campo, tío de Álvaro y Bernal.

${ }^{179}$ Hijo de Gil de Riobóo que atestigua el testamento de Álvaro Pérez de Moscoso, si bien pudo recibir una donación como Gonzalo de Riobóo. En tiempos del siguiente titular estaba en el entorno arzobispal, participando en la batalla de Altamira, abandonándolo poco después y sirviendo al conde con dos lanzas "quando era curador de Arias Vázquez" (En la propia edición de Aponte se indica que algunos manuscritos leen "Carlos Vázquez", que los editores creen, en todo caso, improbable), VA, pp. 183 y 196-197 (n. 261). El hecho de que aparezca referido pronto en la documentación de la casa no implica su afinidad inmediata pero sí que el cambio de entorno no resultó tan peculiar como indica Aponte. Relacionado en el XVI con la merindad de Mens y sus beneficios, CA, p. 446.

${ }^{180} \mathrm{Su}$ hija, Catalina, recibió derechos en la iglesia de Lesta y una dote en el testamento del titular. Aún a principios del XVI aparece un Fernando de Lesta en relación a los beneficios condales en Montaos CA, p. 449.

${ }^{181}$ Hermano de Pedro Mariño. Se le hace una merced testamentaria de 15.000 pares de blancas. Podría tratarse del Alfonso de los Ríos que sirve al siguiente titular. 


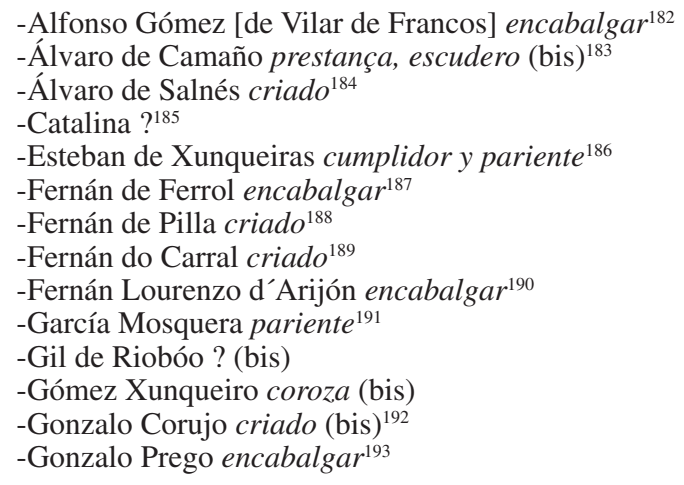

${ }^{182}$ En el testamento de Álvaro Pérez junto a otros. Como de Vilar de Francos aparece junto a Lope Sánchez y Urraca de Moscoso y muchos otros, sin indicar filiación, en una carta real relativa a unas propiedades usurpadas al monasterio de Mourence, AGS, Registro General del Sello, 1486, 10 , f. 107. Junto a otros como "fidalgos de casa del dicho señor conde" en 1504 en la lectura y copia de las mandas testamentarias del conde relativas a Bonaval, p. 131; por ello no es posible establecer si continuaban su servicio con el siguiente conde.

183 Álvaro Pérez de Moscoso pide en su testamento, que se le den 3.000 pares de blancas, probablemente de prestança y 4.000 más por merced. Paralelamente, Lope Sánchez de Moscoso aparece citado junto al mismo en 1495 en una carta de amparo a un vecino de Noia, aunque sin expresar su relación (AGS, Registro General del Sello, 1495, 5, f. 147). En 1504 atestigua la confirmación de Rodrigo Osorio de Moscoso de las mandas del primer conde referidas a Sto. Domingo de Bonaval junto a Esteban de Xunqueiras y Francisco de Reinoso, CA, p. 133.

${ }^{184} \mathrm{El}$ testamento del titular le lega los derechos de una iglesia. Cabe destacar que el propio testamento indica que los en él referidos son criados.

${ }^{185} \mathrm{Vid}$. Alfonso de Lesta.

${ }^{186}$ Aparte del propio testamento del titular hay una manda en el testamento de Lope Sánchez de Moscoso que indica que recibió varias rentas y bienes "al fallescimiento de mi señor Alvaro Perez y de mi señora doña Juana”; también se indica que también Bernal Yáñez pudo tener alguna deuda con él, por la que se le habían cedido durante varios años las rentas del coto de Carrera. CA, p. 112. Vid. supra lo referente a sus enfrentamientos con la casa (en Altamira y Outes) y el ejercicio de la tenencia de Altamira. En 1460 se halla en Rocha Branca junto al arzobispo y en 1463 Alonso de Fonseca I lo menciona como "escudero de nuestra casa" algo que, como vimos, no le impediría terminar colaborando y ejerciendo el oficio de alcaide de Altamira. Sobre su relación con el arzobispado y el mantenimiento de las tierras que su padre tuvo de la iglesia compostelana ACS, IG. 709 / 4, ff. 48-49r y AHDS, Fondo General, Bienes y Rentas de la Mitra, 3, f.140 (editado en A. RoDríGUEZ, Documentación, pp.437-438). Creemos que ya a finales del XV se integró definitivamente en el entorno; aparece junto a otros afines en 1486 (vid. Alfonso Gómez de Vilar de Francos) y, en 1504, aparece junto a Rodrigo Osorio de Moscoso, Álvaro de Caamaño y Francisco de Reinoso.

187 Vid. Alfonso Gómez.

${ }^{188}$ Se le mandan 4.000 pares de blancas en el testamento del titular.

189 Ibidem.

${ }^{190}$ Vid. Alfonso Gómez. En el listado de beneficiados de Mens hallamos a Pedro de Arijoon, CA, p. 446.

${ }^{191}$ Recibe por donación de Álvaro Pérez unos bienes que habían sido de su padre.

${ }^{192}$ Como criado Álvaro Pérez le donó parte de la sinecura de un patronazgo. También sirvió a Lope Sánchez en el testamento, pero se indica que si entrega una carta que le otorgó el conde se le permita llevar "todo lo que mi señor Alvaro Pérez le dio", CA, p. 112. Posiblemente se trate del mismo individuo mencionado en 1486 como Gonzalo d'Orujo, vid. Alfonso Gómez de Vilar de Francos. Relacionado más tarde con los beneficios de Montaos, CA, p. 448.

${ }^{193}$ Vid. Alfonso Gómez. 


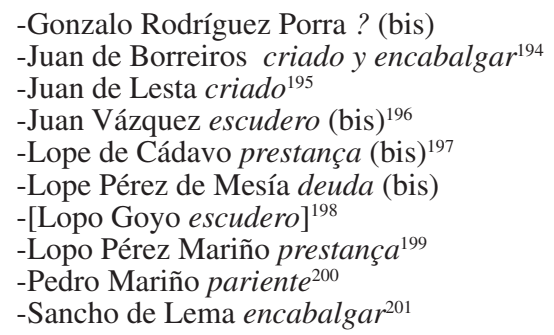

Lope Sánchez de Moscoso (m. 1504) 202

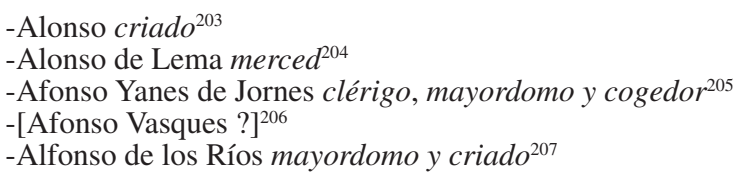

${ }^{194}$ Lo llamativo en este caso es que el testamento de Álvaro Gómez le lega "o paço das Travesas
con súa cortyna".
${ }^{195}$ Recibe una donación en el testamento del titular y a principios del XVI aún disfruta de los beneficios de la merindad de Mens, CA, p. 446.

${ }^{196}$ Aparece en 1466, junto a Lopo Goyo, como escudero de Urraca de Moscoso, no obstante lo asignamos a Álvaro Pérez, CA, p. 261. Se le dona de por vida una propiedad cercana a Santiago en el testamento de 1467. En c.1475, es "escudero e vasalo [do] señor conde de Alta[mira]" y toma posesión de unas propiedades en Guisande, donadas por el vizconde de Fisterra (en Noia en 1474) junto a varios de sus escuderos, en las inmediaciones de de la fortaleza de Altamira de la que sería alcaide, ACS, S. 17 / 22 y CA, pp. 116-117, 125 y 508. Ya había muerto cuando se redacta el testamento del conde, al estar sepultado en S. Francisco de Benavente parece plausible que hubiera muerto acompañando allí al conde. Su hijo Fernando había muerto heredándolo su hija María, tenía otro hijo llamado Juan que estaba desaparecido. En 1500, su hijo, Alfonso Vázquez, vende un tercio de las propiedades de Guisande que le pertenecían por herencia de la donación condal, ACS, P. 002, f. 129. Aún en 1569 hallamos un Alfonso Vázquez como escribano en la audiencia condal, ACS, P. 044, f. 144v. En el testamento se dona a su viuda Maior Vázquez.

${ }^{197} \mathrm{Se}$ le adeudan en el testamento del titular 3.000 pares de blancas por ella.

${ }^{198}$ Vid. Juan Vázquez.

${ }^{199}$ Se le adeudan en el testamento del titular 3.000 pares de blancas por ella.

${ }^{200}$ Merced testamentaria de 25.000 pares de blancas. Hermano de Alfonso do Río.

${ }^{201}$ Vid. Alfonso Gómez. Cabe destacar que en 1438 hemos hallado un Fernán de Lema, fiel de las rentas reales en Muxía, AHDS, Fondo General, Bienes y Rentas de la Mitra, 28, f. 75.

${ }^{202}$ En un resumen de la nómina de la boda de Lope hallamos a Ruy Tato, Gonzalo López de Riobóo, Gómez de Ventosa, Álvaro de Rendal, Gómez Alonso de Arcén, Álvaro de Caamaño, Martín de Leis de Leboráns y Martín de Becerra. Ruy Soneira estuvo, si bien nosotros sólo contamos a su hijo. Aparece también Martín Romeu que serviría al siguiente titular, igual podría suceder con García de Ardeleiro. CA, p. 45.

${ }^{203}$ De Urraca de Moscoso, CA, p. 101.

${ }^{204}$ Casado con Urraca de Gontín, se indica que nunca se le dotó por lo que, si se le quiere quitar la merced, han de pagársele 10.000 mrs, CA, p. 120 y 123.

${ }^{205}$ En 1486, aparece como clérigo, vid. Alfonso Gómez de Vilar de Francos. En la pesquisa realizada por el mayordomo del conde, vid. Alfonso de los Ríos, se le pide junto a Lopo Alonso de Mees que declaren las rentas de la merindad correspondiente ya que "foran mayordomos e cogedores de las rentas e derechuras devydas al dicho señor conde", CA, pp. 266-269.

${ }^{206}$ Vid. Juan Vázquez.

${ }^{207}$ Su relación con la casa está clara, en 1493 actúa como mayordomo puesto que siendo el cura de la iglesia de S. Miguel de Treos aforó en 1499 varias propiedades del Conde de Altamira, incluyendo 


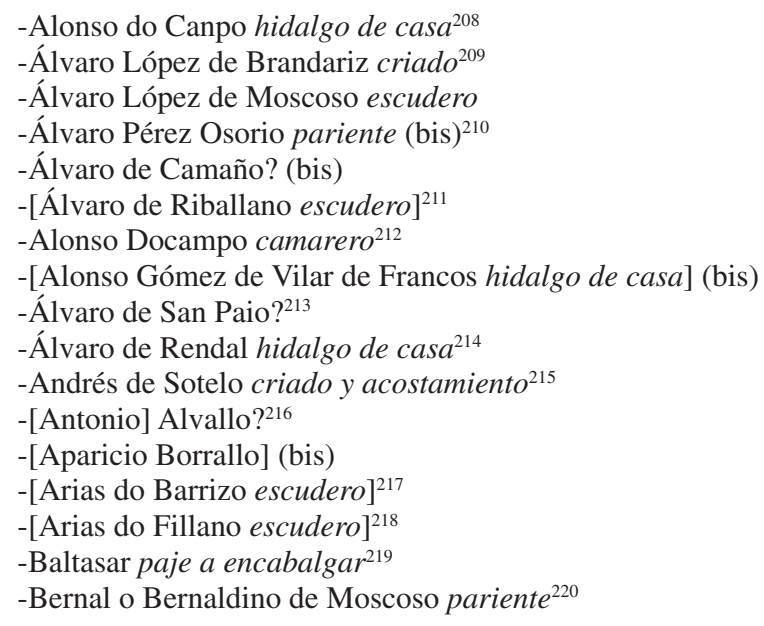

una torre y palacio, dentro de la ciudad de Santiago (ACS, P. 002, ff. 259-261). A. M. FRAMIÑÁn, Notas, pp.356-357 y CA, p. 266. Debió fallecer poco antes que el propio conde, vid. Lope Sánchez y Francisco de Collantes.

${ }^{208}$ Vid. Martín de Reino.

${ }^{209}$ Se le dota para casamiento en el testamento del primer conde. Será merino de Ventosa con el siguiente. CA, pp. 113 y 583-585 y A. M. FRAMIÑÁN, Notas, p. 343. Hay cierta confusión documental entre éste y el siguiente puesto que podrían hallarse emparentados. Aparece un Álvaro López como escudero del conde en 1482 vendiendo dos casales a un racionero de la catedral compostelana (ACS, S. 16/35). En 1485 Álvaro López de Moscoso, "escudeyro del conde" realiza una venta de unos bienes en Santiago "de que vos teendes a outra meetade por contrabto de vendia que del vos fezo [Álvaro ¿Lopes?] de Brandariz, meu yrmaao... por herençia e susçession de nosa señora madre Costança Lope", ACS, S. $18 / 45$.

${ }^{210}$ Hijo de Urraca de Moscoso que hizo carrera eclesiástica con cierto éxito (llegó a ser obispo de Astorga) y, que junto a Pedro Bermúdez, participaría en dirigir el condado en la ausencia del II Conde de Altamira. CA, pp. 104, 581-582

${ }^{211}$ Mencionado, junto a varios más, en una carta de los reyes de 1480 en la que se informa de que Aldonza Rodríguez se quejaba de que Urraca de Moscoso había usurpado la bailía de Padrón y otras propiedades, siendo atacada por varios "escuderos e gentes de la dicha dona Vrraca" que mataron a varios de sus criados, AGS, Registro General del Sello, 1480, 10, f. 52. La relación resulta dudosa puesto que podría pertenecer originalmente al entorno del difunto marido de Urraca, Pedro Osorio.

${ }^{212}$ Hijo de Pedro Docampo, vecino de Zamora. Las mandas testamentarias consisten 20.000 pares de blancas, todos los vestidos del conde, varios enseres y una acémila, CA, p. 117.

${ }^{213}$ Vid. Alfonso Gómez de Vilar de Francos.

${ }^{214}$ Casado con Sancha Fernández que tenía unas rapadas de pan en "préstamo" de Urraca de Moscoso. Atestigua la copia del testamento condal de 1504. En el listado de c.1528 aparece en relación a beneficios en la merindad de Cira. CA, pp. 102, 131 y 451. Sobre el origen del servicio a los Moscoso podría derivar de la casa de Ulloa, puesto que en 1430 hay un Ruy Pérez de Rendal escudero de Lope Sánchez de Ulloa, abuelo del I conde de Altamira, AHDS, Jurisdiccional, 11, cuaderno $3^{\circ}$, f. 50.

${ }^{215} \mathrm{Su}$ acostamiento era de $4.000 \mathrm{mrs}$ anuales, se le mandan 10.000 para casamiento, CA, p. 117.

${ }^{216}$ Vid. Alfonso Gómez de Vilar de Francos.

${ }^{217}$ Vid. Álvaro de Riballano.

${ }^{218}$ Ibidem.

${ }^{219}$ Hijo del bachiller Juan de Vargas, vid. Fernando de Lema.

${ }^{220}$ Hijo de Urraca de Moscoso y de Pedro Osorio al que se le mandan los frutos, rentas, derechos y jurisdicción en Val da Barcia, CÁ, pp. 97 y 116. 


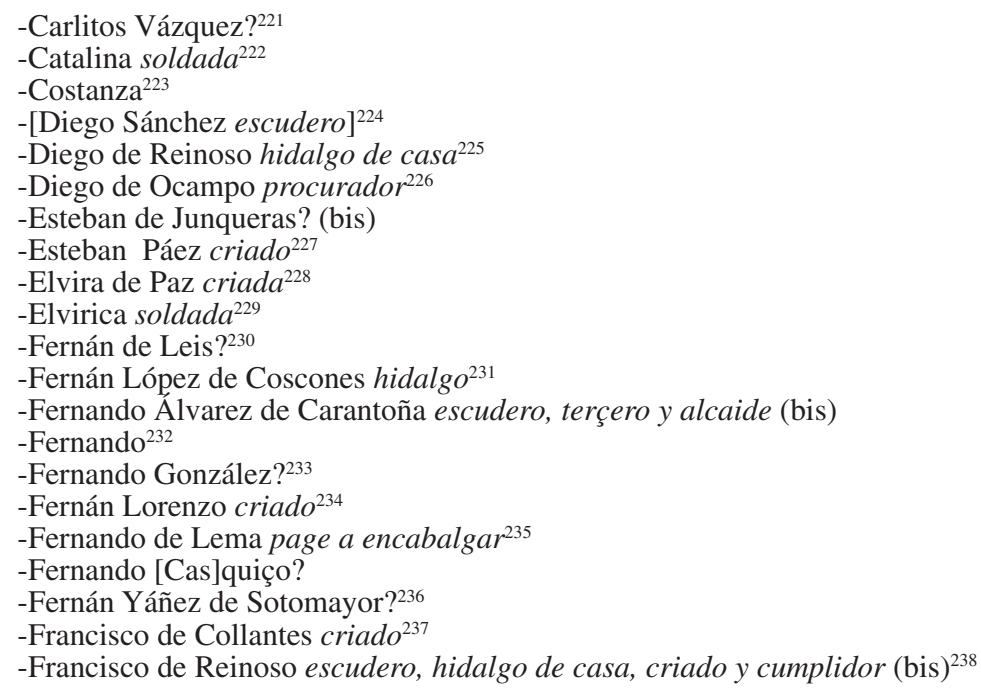

${ }^{221}$ Vid. Antonio Alvallo y Gonzalo López de Riobóo.

${ }^{222}$ CA, p. 124.

${ }^{223}$ Vid. Gonzalo Pensado.

${ }^{224}$ Vid. Álvaro de Riballano.

${ }^{225}$ Recibe como hidalgo el homenaje de Gonzalo Pérez en 1480 como garantía del acuerdo matrimonial con el conde de Benavente. M. J. VÁZQUEZ, Los condes, p. 264. Atestigua en 1504 las mandas relativas a Bonaval, vid. Alfonso Gómez de Vilar de Francos.

${ }^{226}$ Procurador del I Conde en 1488 (AGS, Registro General del Sello, 1488, 10, f. 38). Aparece en AHDS, Fondo General, Catálogos, n ${ }^{\circ}$, f. 72v, pese a que la referencia, sin datar, es de un inventario de escrituras, lo hallamos como alcaide de Altamira en 1516, ACS, S15/53.

${ }^{227}$ Criado de Urraca de Moscoso al que se le lega una ayuda para casamiento, CA, p. 100.

${ }^{228}$ Casada con Ruy Tato y mencionada como tal.

${ }^{229}$ De Urraca de Moscoso, CA, p. 101.

${ }^{230} \mathrm{Vid}$. Alfonso Gómez de Vilar de Francos.

${ }^{231}$ Procedente de tierra de Trastámara y muerto en 1471 en los enfrentamientos con el arzobispo, VA, p. 187. Sobre sus posibles padres y el origen de su servicio a la casa, vid. Fernán López de Lamas.

${ }^{232}$ Hijo de Fernando Álvarez de Carantoña, encomendado en el testamento condal, CA, p. 117. En el listado de 1510 hay cierta confusión pues aparecen Fernán Álvarez el mozo y Fernán Âlvarez de Corcubión, si bien el primero obtiene sus rentas en Laxe, CA, p. 468 y472.

${ }^{233}$ En su testamento Urraca le manda una propiedad que había sido de sus antepasados pero se indica "por el travajo que paso con mi fijo en la yda de Flandes", CA, p. 101.

${ }^{234} \mathrm{CA}$, pp. 111, la manda testamentaria del titular consiste en una casa, con sus heredades y molino.

${ }^{235}$ CA, p. 124.

${ }^{236}$ Con una lanza al servicio del conde, VA, p. 197 y atestiguó, sin filiación, la dote de Francisco de Reinoso en 1482.

${ }^{237}$ Encarcelado junto a Ruy Tato, Alonso de los Ríos, Juan Pardo y Fernán Álvarez de Corcubión por Pedro de Almança, alcalde mayor del arzobispo de Santiago, VA, pp. 200-201.

${ }^{238}$ Asistió al homenaje por Altamira en enero de 1480. Lo relativo a su casamiento en 1482 con Juana Ferrera, criada de la reina doña Juana, en ARCHV, Pergaminos, Carpeta 163, 5. En 1498 atestiguó una carta de pago en Santiago, vid. Martín de Reino. En el testamento condal se aportan numerosos datos sobre su relación con la administración de la hacienda del titular, además se le manda "el mejor cavallo que yo toviere". Aparte del servicio a la casa era justicia y alcalde ordinario de 


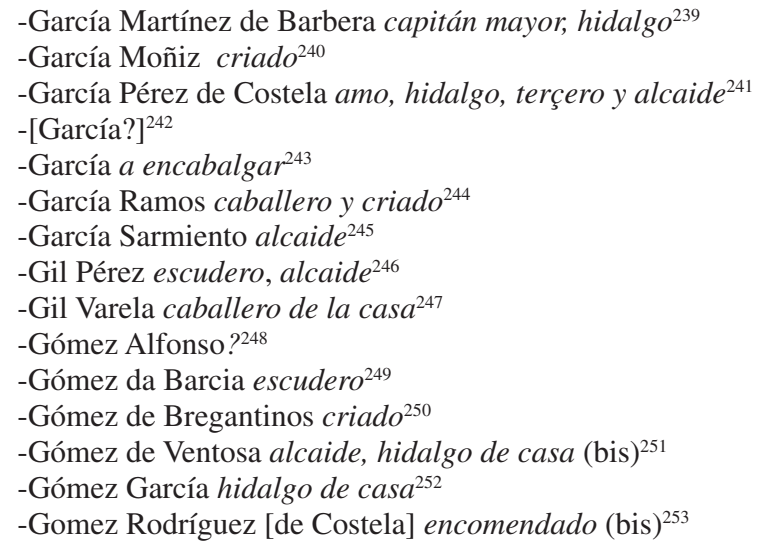

la ciudad de Santiago, CA, pp. 113-114, 120 y 127. En 1503 como "fidalgo de la casa del magnifico señor conde de Altamira, vezino de la ciudad de Santiago" da un censo perpetuo atestiguado por su criado Lopo de Castro, ACS, S. 17 / 34. Vid. Álvaro de Camaño.

${ }^{239}$ Es nombrado, el 22 de julio de 1470, por parte de Lope Sánchez de Moscoso como unos de los hidalgos que deliberará sobre el acuerdo con Sancho de Ulloa sobre la herencia de Lope Sánchez de Ulloa el viejo ACS, LD. 9/2, f. 10. En VA, p. 197 se indica que tenía 10 lanzas de las 80 que tenía toda la casa. Sobre el resto de su trayectoria vid. supra.

${ }^{240}$ CA, p. 112.

${ }^{241}$ Nombrado como parte de los hidalgos que deben decidir en 1470 sobre la herencia de Lope Sánchez de Ulloa. En 1479 era alcaide de Cira, realizando homenaje en Benavente, para ser nombrado alcaide de la fortaleza de Altamira, que iba a ser puesta en tercería por el acuerdo con Benavente, como tal es mencionado en agosto de ese mismo año, estando presente en el homenaje por la fortaleza de Altamira enero de 1480. M. J. VÁzQuEZ, Los condes, pp. 251-254 y CA, p. 559. Su hijo, Gómez Rodríguez de Costela, era alcaide y merino de Altamira en 1510. A. M. FrAMiÑÁn y X. A. García, Os Costela, p. 159.

${ }^{242}$ Hijo de Fernán Ares de Leis, se le confirma una donación a perpetuidad de unas propiedades "que su padre llebo por mi" en Soneira, CA, p. 118.

${ }^{243}$ Hijo de Fernán García del Campo, vid. Fernando de Lema.

${ }^{244}$ Junto a Gonzalo Osorio acompañó al conde en Benavente y atestiguó el juramento de García Pérez de Costela, M. J. VÁzQUEZ, Los condes, p. 252.

${ }^{245}$ En la fortaleza de Altamira. En 1494 se le otorga una carta de pago por una dote y obligación de $45.000 \mathrm{mrs}$, ACS, P. 002, f. 1.

${ }^{246}$ Se menciona como alcaide de Cira en mayo de 1478, M. J. VÁzQUEZ, Los condes, p. 255

${ }^{247}$ Estuvo en 1479 en los acuerdos de liberación del conde de Camiña, en 1489 compra unas propiedades en Berreo por valor de $10.000 \mathrm{mrs}$, pero aparece como "Gil Varela de Vilamide escudeiro da señora dona Orraca de Moscoso"; CA, p. 554 y ACS, S. 17 / 27.

${ }^{248}$ Lo identificamos como criado pues se le dan $2.500 \mathrm{mrs}$, "allende lo que le tengo dado e casamiento", CA, p. 112.

${ }^{249}$ Se le dotó para su casamiento con Marina de Ulloa, CA, p. 508 y vid. Gonzalo Rodríguez Porra.

${ }^{250}$ Se dota para casamiento y "si yo moriere antes que sea el sea para rescevir armas y cavallo que ge lo de mi heredero y bueno y se sirva del y le faga merced", CA, p. 118.

${ }^{251}$ Atestigua el testamento del conde en el que se menciona que tenía un censo de unos palacios y propiedades en la zona de Cira. En torno a 1500, ya era alcaide de la misma, apareciendo en una indagación en la zona respecto a las propiedades condales, que no había sabido gestionar o había malvendido,se le menciona, CA, pp. 114, 127, 278-280 y 285 .

${ }^{252}$ Vid. Martín de Reino.

${ }^{253}$ Fue encomendado al siguiente titular, CA, p. 114 y vid. García Pérez de Costela. 


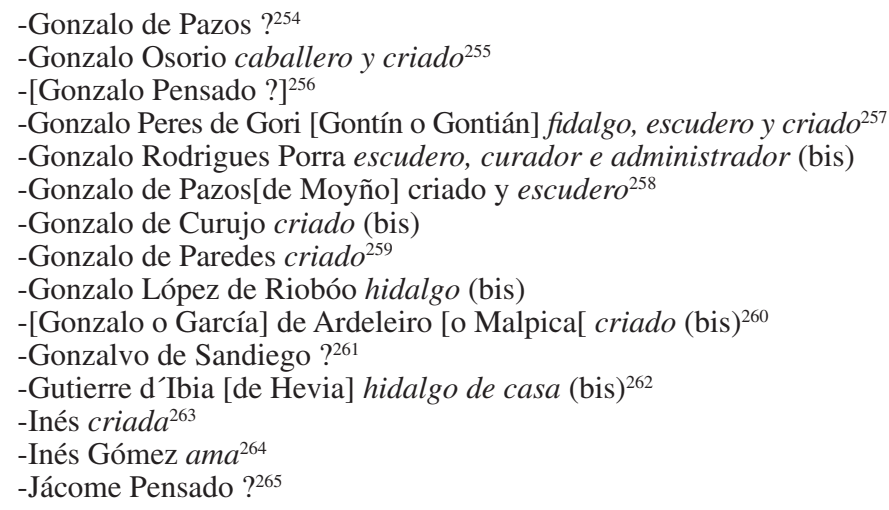

${ }^{254}$ Vid. Alfonso Gómez de Vilar de Francos.

${ }^{255}$ En la puesta en tercería de la fortaleza de Cira vuelve a estar presente pese a que no se indica filiación junto a Juan Pimentel, que pertenecía a la casa del conde de Benavente, M. J. VÁZQUEZ, Los condes, p. 254.

${ }^{256}$ En este caso el testamento condal indica sólo que se le mantenga un foro, pero se indica que si el conde no casa a su hija que se le de una dote y vestido. Después del segundo titular se le menciona en relación a los beneficios de la merindad de Altamira, CA, pp. 120 y 450.

${ }^{257}$ En VA, p. 195, se indica que fue merino de Morgade y que estaba casado con una hermana bastarda del conde, Leonor de Ulloa (respecto a su dote y a su criada vid. CA, pp. 111 y 117). En 1480 realiza, como alcaide y tenedor de esa fortaleza, homenaje para el acuerdo matrimonial con Rodrigo Alonso Pimentel, conde de Benavente, M. J. VÁZQuEZ, Los condes, pp. 265-266. Servía a la casa con 2 lanzas VA, p. 197. Aparece referido en las usurpaciones a Mourence, vid. Alfonso Gómez de Vilar de Francos.

${ }^{258}$ Es hijo de Rui Soneira, vid. Diego de Leis y Mencía Vázquez, hermano de Rodrigo de Leis, se le mandan 20.000 mrs. CA, p. 111. Como Gonzalo de Pazo de Muyño aparece donando perpetuamente el patronato de la iglesia de Sta. María de Ons a Juan García, canónigo de Santiago, que se lo había donado previamente ACS, S 16/31, uno de los testigos podría ser criado del propio Gonzalo de Pazos. En este caso podría haber confusión entre dos individuos distintos.

${ }^{259}$ CA, p. 112.

${ }^{260} \mathrm{Si}$ bien pueden ser dos individuos diferentes, Aponte refiere el apellido de este criado que puede identificarse con Gonzalo o García de Ardeleiro que aparecen algo después, VA, pp. 200 y vid. Alonso de Celís. En la lista de beneficios de c. 1528 aparece un Gonzalo en relación con los de Mens.

${ }^{261}$ Vid. Alfonso Gómez de Vilar de Francos.

${ }^{262}$ Casado con Sancha Oanes. En 1498 forma parte del entorno señorial, vid. Martín de Reino. Acompañó al conde a Montserrat. Su implicación económica para con el II conde de Altamira queda reflejada en los codicilios de 1510 en los que el conde indica que se le restituyan ciertas cantidades "por todo lo que por mi gasto en esta santa empresa", CA, pp. 118, 138, 588-591, 597. Tal vez fuera su propio endeudamiento lo que le llevó a ser encarcelado brevemente en Vimianzo tras la muerte del conde y objeto de varios juicios de residencia por su administración de las rentas de la casa. La presencia de un individuo con el mismo nombre en 1524 en Melide como probable afín arzobispal en ACS, IG 711/4, f. 3v, parcialmente estudiado en Guillermo Federico Carlos FRAGA, Referencias a las armas utilizads en las luchas nobiliarias gallegas en el siglo XV), en Las Armas en la Historia (siglos X-XIV) (B. PALACIOS, dir.), "Gladius", vol. especial (1988), pp.103-105. A mediados del XVI hallamos a Rodrigo Devia alcaide de Altamira, ACS, P. 026, f. 258, AHUS, Protocolos Notariales, N-93, f. 38 y ARCHV, Pleitos Civiles, Pérez,Alonso (F), caja 35, exp. 1 , cuaderno suelto de feudos y escrituras, ff. $4 \mathrm{v}-13 \mathrm{r}$. Este apellido sigue apareciendo a lo largo del XVI en documentación relacionada con los condes de Altamira, especialmente en el valle de Amaía.

${ }^{263}$ De Urraca de Moscoso, CA, p. 101.

${ }^{264}$ CA, p. 102.

${ }^{265}$ Vid. Alfonso Gómez de Vilar de Francos. 


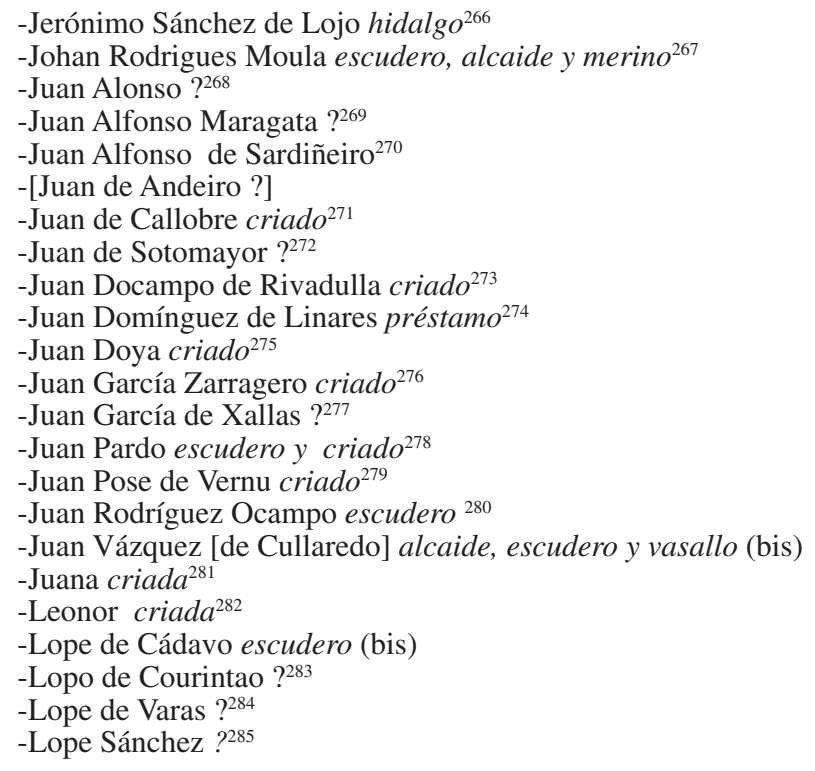

${ }^{266}$ ACS, LD. 9/ 2,f. 10.

${ }^{267}$ Era hijo de García Martínez de Barbeira. En abril de 1474 estaba en la fortaleza de Vimianzo. AHDS, Fondo General, Bienes y Rentas de la Mitra, 28, ff. 126/144 y 131/14. Aparece en julio de ese año en Noia referido como escudero. Vid. Juan Vázquez.

${ }^{268}$ CA, pp. 113 y 117 y Vid. Alfonso Gómez de Vilar de Francos. También aparece en 1540 un Juan Barbeyra, "teniente de merino en dicha villa de Corcobión”, que podría estar emparentado, vid. ASPA, Condado de Altamira, 3A1/ 66, f. 10r y VA, p. 103.

${ }^{269}$ Vid. Alfonso Gómez de Vilar de Francos.

${ }^{270}$ Ibidem. En este caso no hay confusión posible con los anteriores por aparecer juntos en un mismo documento.

${ }^{271}$ Relacionado en el XVI con beneficios en la merindad de Mens, CA, pp. 119 y 446.

${ }^{272}$ Era hijo de Suero Gómez de Sotomayor, por lo que puede pensarse que había sido asignado temporalmente por la casa paterna al conde de Altamira, "que siempre lo acompañaba con tres o quatro escuderos", VA, p. 197.

${ }^{273}$ Padre de Rui Gómez Docampo que llevaba parte del beneficio de S. Fiz de Sales, CA, p. 113

${ }^{274}$ Por Urraca, CA, p. 102.

${ }^{275}$ Se le dota para casamiento, CA, p. 111.

${ }^{276}$ En este caso, la manda testamentaria del conde especifica "que agora esta ciego". CA, p. 112.

${ }^{277}$ Vid. Alfonso Gómez de Vilar de Francos.

${ }^{278}$ Hijo de Pedro Pardo, casado con María Vázquez, hija de Juan Vázquez, a la que aún en 1500 no se la había dado su dote para casamiento; debió morir en el cerco de A Coruña, CA, pp. 116-118 y VA, p. 200.

${ }^{279}$ CA, p. 123.

${ }^{280}$ Era pariente del conde pero se integró en el entorno junto a Gonzalo López de Riobóo.

${ }^{281}$ Hija de un García Rodríguez, criada de Urraca de Moscoso, CA, p. 101.

${ }^{282}$ Criada de Urraca a la que dota en su testamento, CA, pp. 100-101.

${ }^{283}$ Vid. Alfonso Gómez de Vilar de Francos.

${ }^{284}$ Ibidem.

${ }^{285}$ Hijo de Afonso de Río, manda de 10.000 mrs "si seguire el estudio"; de lo contrario la mitad, CA, p. 112. 


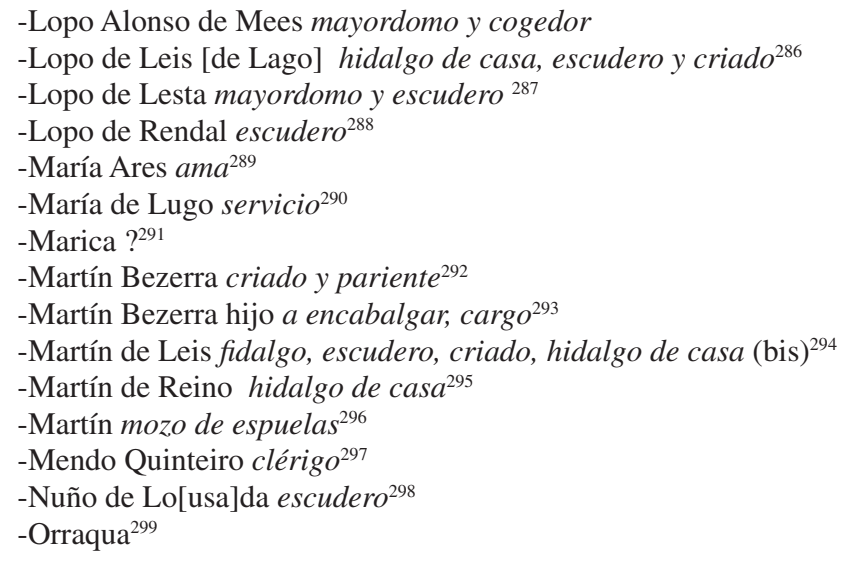

${ }^{286}$ En 1488 tiene un pleito por unas propiedades con el monasterio de S. Martiño, AHUS, Colección Blanco Cicerón, Pergaminos, $n^{\circ} 64$ (regestado en M. LUCAS, El archivo, pp. 646-647). Casado con María Álvarez y con una hija, María de Leis. Aparece en 1486, vid. Alfonso Gómez de Vilar de Francos.

${ }^{287}$ Mencionado como tal en 1482, CA, p. 193. Dos años después como escudero junto a Nuño de Lousada, vid. Lopo de Rendal.

${ }^{288}$ Como tal respecto a una propiedad (Sta. María de Pérros) cercana a la fortaleza de Altamira en 1484, resulta llamativo que la propiedad monacal derivaba de un poder de Diego de Muros, obispo de Tui y administrador del monasterio, que colaboró con el conde de Altamira. En 1486 y 1488 afora una casa en Santiago y dos propiedades más, una en la misma feligresía y otra en la vecina de S. Xiao de Bastavales, si bien no se especifica siempre la relación estaba acumulando patrimonio en una zona de interés para otros afínes, como Juan Vázquez. AHUS, Colección Blanco Cicerón, Pergaminos, nº 18 y M. LUCAS, El archivo, pp. 247, 251-252 y 488.

${ }^{289}$ De Urraca de Moscoso, CA, p. 102.

${ }^{290}$ CA, p. 101.

${ }^{291}$ Hija del criado Pedro Lozano.

${ }^{292}$ CA, pp. 123-124.

${ }^{293}$ Ibidem. Donó al conde sus derechos en la zona de Corcubión, CA, p. 504.

${ }^{294}$ Vid. notas 39-42 y Fernán Casquiço. Tiene una prestança, su servicio se relaciona en este momento con la merindad de Vimianzo, puesto que el salario de Ruy Calvo, "cojedor e guardador de la camara de la merindad", sale de lo que recibía él del conde y, tiempo después, se le menciona en el listado de beneficio de la misma. CA, pp. 447 y 472-473. En 1504 junto a Diego de Reinoso y otros.

${ }^{295}$ Atestiguó la dote de 1486 de Francisco de Reinoso como "fidalgo de casa". En 1498 otorga una carta de pago al conde, atestiguada por varios "fidalgos de casa del dicho señor conde", correspondiente a las alcabalas de los señoríos condales de 1483, subarrendadas al recaudador de las alcabalas del arzobispado, ACS, P. 001, f. 109. El hecho de participar como intermediario en el cobro, y el mantener una deuda con el titular, nos permite asignarlo como afín ya desde entonces. En un inventario de escrituras de c. 1512 se anota al lado de un pleito "He de saber Martin de Reyno quien lo lleva o como", por lo que seguía con vida pero el hecho de no mencionarlo en los acostamientos de 1510 puede indicar que ya no servía directamente a la casa, CA, p. 503; aunque en 1574 tenemos constancia de un Gonzalo Suárez de Reino residente de la audiencia condal ACS, P. 059, ff. 257-258.

${ }^{296}$ Se le mandan $4.000 \mathrm{mrs}$ y que se le vista, CA, p. 113.

${ }^{297}$ Ganó una carta real para justificar su usurpación del beneficio de Fuentecada, "dis que el dicho conde tovo maña con vn clérigo... que le ocupase la dicha rrenta", mientras el conde engañaba al verdadero beneficiario para que no se quejase, AGS, Registro General del Sello, 1486, 10, f. 35 (editado en M. J. VÁZQUEZ, Los condes, pp. 270-271).

${ }^{298}$ Junto a Lopo de Lesta, en 1484, en el aforamiento realizado por Lopo de Rendal.

${ }^{299}$ Criada dotada por el testamento de Urraca de Moscoso, CA, p. 100. 


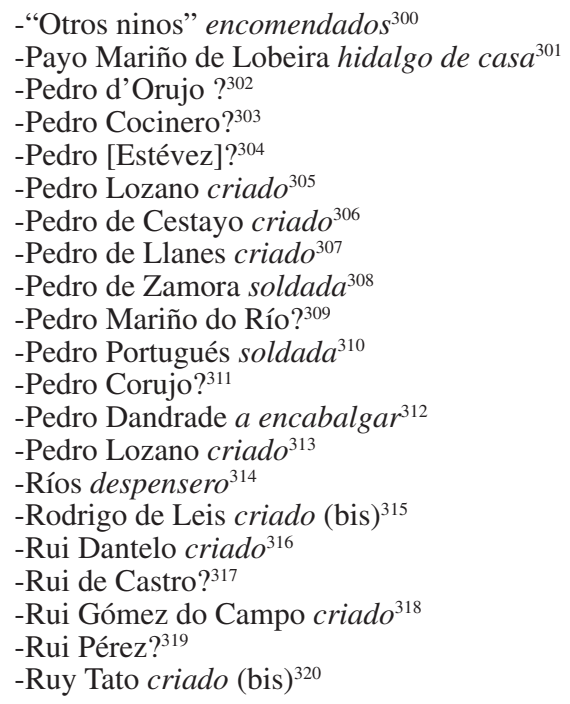

${ }^{300}$ El testamento de Urraca indica que "los otros ninos que estan en casa que les den bien de vestir...e sy quisieren bebir con mis fijos e servirlos encomendogelos para que fagan dellos criados", CA, p. 102.

${ }^{301}$ Vid. Alfonso Gómez de Vilar de Francos.

${ }^{302}$ Ibidem para 1486.

${ }^{303}$ Que se le paguen deudas y se le de para vestir, CA, p. 124.

304 Vid. Alfonso Gómez de Vilar de Francos.

${ }^{305}$ De Urraca, CA, p. 100.

${ }^{306}$ Se le dota para casamiento, CA, p. 111.

${ }^{307}$ CA, p. 112.

${ }^{308}$ A él y su mujer Catalina, que se les vista si quieren irse si no se los encomienda, CA, p. 124

${ }^{309}$ Servía a la casa con dos lanzas, VA, p. 197.

${ }^{310}$ Vid. Pedro de Zamora.

${ }^{311}$ Aparece junto a Gonzalo de Curujo usurpando heredades en Vines, Dorujo y Geytoso (AGS, Registro General del Sello, 1488, 10, f. 38).

${ }^{312}$ Hijo de Pedro de Andrade (que podría ser uno de los mencionados en VA, p. 133 y J. F. CoRREA, A casa, p. 387, que se pasó de los Andrade a los Mariñas), que se le den armas y 10.000 pares de blancas para casarlo, CA, p. 118

${ }^{313}$ Urraca de Moscoso le lega unas propiedades que deben revertir en la casa, CA, p. 100-101.

${ }^{314}$ CA, p. 124.

${ }^{315}$ Vid. Martín de Leis. Relacionado con la zona de Muros y Noia, en 1510 mantenía su prestanza de la merindad de Carnota. En 1514 aparece mencionado como regidor en la villa de Noia. Su servicio coyuntural a la casa debe relacionarse con el de su padre a la misma; entre 1510-1512 tuvo el arriendo de las rentas del partido de Altamira reclamándosele el pago de las mismas, vid. CA, pp. 369-370 y 473.

${ }^{316}$ Se le adeuda lo correspondiente a su matrimonio, CA, p. 112.

${ }^{317}$ Vid. Alfonso Gómez de Vilar de Francos.

${ }^{318}$ Vid. Juan Docampo de Rivadulla. Hay un Rui Gómez en el listado de beneficiados de Mens, CA, p. 446.

${ }^{319}$ Vid. Rui de Castro.

${ }^{320}$ Estuvo en la boda del I Conde, fue "pagador de los fueros quel Conde deve" con el siguiente titular. Se le dio carta de pago por su matrimonio con Elvira de Paz, lo que despertó ciertas disputas económicas que no se intentaron solventar en el testamento. Respecto a la destrucción de unas pro- 


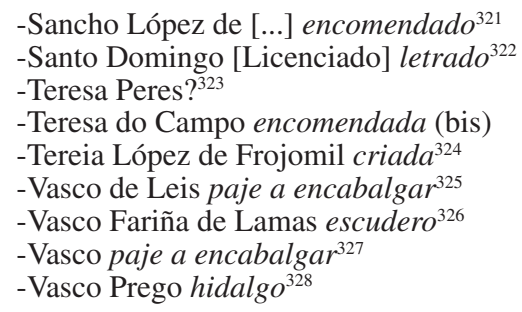

\title{
Rodrigo Osorio de Moscoso (m. 1510)
}

\author{
-[...]Couceiro escudero ${ }^{329}$ \\ -[Alfonso Gómez de Vilar de Francos hidalgo de casa] (bis) \\ -Alonso de Celis hidalgo y criado de casa ${ }^{330}$ \\ -[Álvaro de Caamaño?] (bis) \\ -Álvaro López de Brandariz merino (bis) \\ -Álvaro Pérez Osorio pariente (bis) \\ -Brandariz prestança y merino (bis) ${ }^{331}$ \\ -Diego de Cavana criado $^{332}$ \\ -[Diego de Ocampo alcaide] (bis) \\ -Diego García de San Pero de Río acostamiento $^{333}$
}

piedades condales en tiempos del siguiente titular, vid. CA, 286. Aún en 1532, un individuo homónimo, tenía aforadas unas propiedades condales en Santiago, AHUS, Protocolos Notariales, S-169, ff. 238r-239v y ff. 262(bis)r-263(bis)r y CA, pp. 113, 469 y 475. Vid. Francisco de Collantes.

${ }^{321}$ Vid. Alfonso Gómez de Vilar de Francos. Probablemente se trata de uno de los hijos de Fernando Álvarez de Carantoña a los que se encomienda y dota para casamiento con 6. 000 mrs, CA, p. 117.

${ }^{322} \mathrm{Su}$ relación con este titular queda recogida por los acostamientos de 1510 CA, p. 475.

${ }^{323}$ Ibidem.

${ }^{324}$ Urraca de Moscoso le lega varias propiedades y bienes de cierta importancia, CA, pp. 100 y 104.

${ }^{325}$ Hijo de Martín de Leis, CA, p. 124.

${ }^{326}$ En la carta real relativa a Xallas junto al Conde de Altamira, Diego de Muros y Suero Gómez de Sotomayor. La adscripción al entorno señorial parte de que la pugna por esa fortaleza derivaba de los intereses territoriales de los Moscoso en la zona, desde tiempos de Ruy Sánchez de Moscoso, tenente de la misma en 1402, ACS, IG 703 / 8, f. 64 (ya editado en Antonio LóPEZ, Historia de la Santa A. M. Iglesia de Santiago, Santiago de Compostela,1898-1904, t. VII, ap. II, pp. 6-8), Rodrigo de Luna había prometido entregarla a Bernal Yáñez, ACS, IG. 703 / 28, f. 133), y fue prometida en la concordia a Álvaro Pérez por el arzobispo Alonso de Fonseca II, C. J. GALBÁN, El señorío, pp. 152 y ss. Se le refiere en relación al disfrute de beneficios en Mens, CA, p. 446. Además, en su testamento de 1540, Álvaro Nunes de Lamas intenta poner a sus hijos al cuidado de Lope Osorio de Moscoso "e de sus subçesores como yo e mis anteçesores siempre fuymos servydores de su senoria e de su casa y anteçesores". Vid. ARCHV, Pleitos Civiles, Varela (F), caja 40, exp. 5, cuaderno cosido, f. 1-3.

${ }^{327}$ Hijo de Lope Rodríguez. Vid. Fernando de Lema.

${ }^{328}$ ACS, LD. 9/ 2, f. 10.

${ }^{329}$ Lo refiere VA, p. 207: "un escudero del linaje dos Couçeiros (aunque no eran fidalgos eran criados viejos y muy leales) éste, como iba en las espaldas del conde, disparósele una ballesta que llevaba armada".

${ }^{330}$ Atestigua el testamento del conde redactado en 1507 junto a Martín Romeu, Sancho López de Santiso y Gonzalo de Ardeleiro, CA, pp. 133 y 137.

${ }^{331}$ CA, p. 471. Podría tratarse de Álvaro López de Brandariz, pero su identificación, como en el caso de Álvaro Lopez no es concluyente.

${ }^{332}$ Aparece junto a Rodrigo de Soo y Ruy Lopes Teyxeiro como "criados del conde mi señor" como testigos de la residencia a Gutierre de Hevia en Navia y Burón, CA, p. 225.

${ }^{333}$ CA, p. 474. 


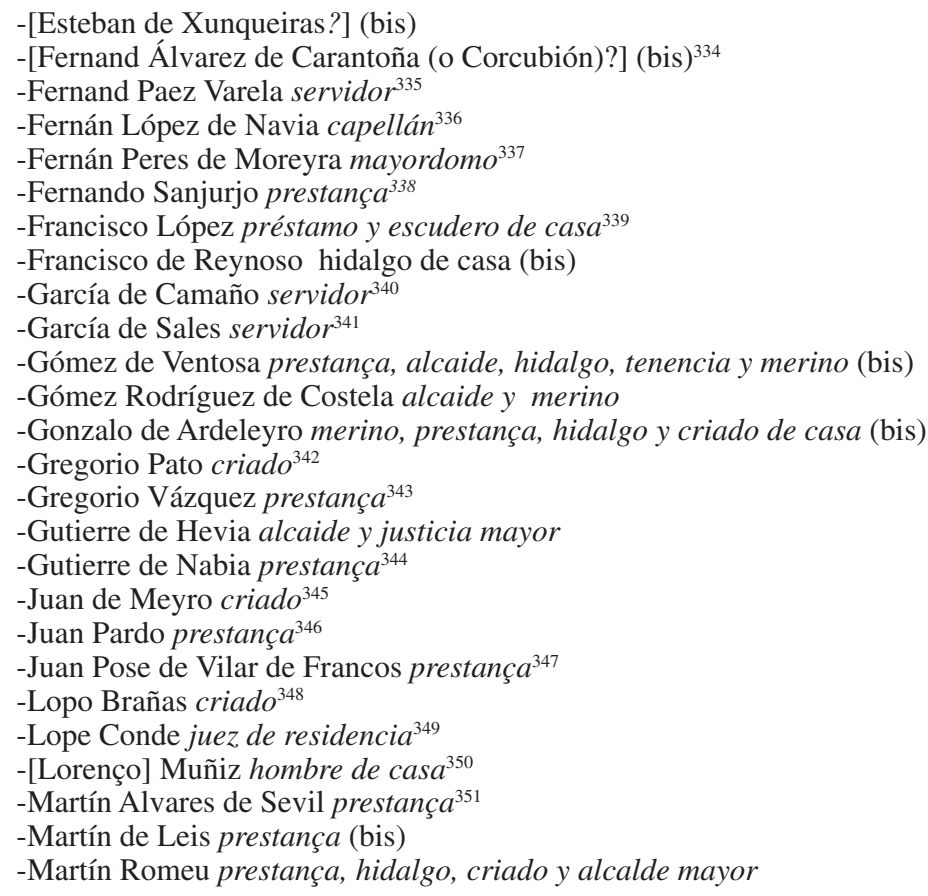

${ }^{334}$ Vid. Fernando.

${ }^{335}$ Se le dota para casamiento encomendándolo a Pedro Bermúdez de Montaos junto a otros escuderos, CA, p. 135.

${ }^{336}$ En 1509, junto a varios escuderos y criados, atestigua en Altamira un foro; probablemente como parte del séquito condal, ASPA, Condado de Altamira, 6F3/718.

${ }^{337}$ Mencionado como tal en la zona de Cereixa en 1507, dentro del juzgado de Soneira CA, p. 337.

${ }^{338}$ Merino de Deza en 1510, CA, p. 471.

${ }^{339}$ CA, p. 470. Como "escudero de su señoria", vid. Fernán López de Navia.

${ }^{340}$ Vid. Fernando Páez. Sobre su relación con su familia, F. BOUZA, El señorío de Villagarcía, pp. 104 y 108.

${ }^{341}$ Ibidem.

${ }^{342}$ Ibidem.

${ }^{343}$ CA, p. 471. Se le nombra merino en 1510 .

${ }^{344}$ Alcaide y merino de Nabia en 1510, CA, p. 474

${ }^{345}$ Vid. Fernán López de Navia.

${ }^{346}$ Será teniente de capitán por el siguiente titular, CA, p. 472.

${ }^{347}$ Se indica que para mantenerla "a de tener caballo", CA, p.472.

${ }^{348}$ Vid. Fernán López de Navia.

${ }^{349}$ CA, pp. 223 y ss.

${ }^{350}$ Acompañó al conde en la toma de Bugía en 1510. Tres años antes aparece referido un Monis "moço de espuelas" que podría ser éste o Pedro Monis, que podría formar parte del acompañamiento habitual del conde. No obstante, el apellido aparece ya en tiempos de Lope Sánchez con García Moñiz "fijo de Diego Moñiz". CA, pp. 587 y 341. Sobre los servicios de otro individuo con este apellido, vid. Fernándo Páez.

${ }^{351}$ CA, p. 469. En 1522 era alcaide y merino de Cira; aún en 1534 hay un Gonzalo de Senbil mayordomo y teniente de merino allí, AHUS, Clero, Mitra, leg. 53. 
-Pedro Moñiz escudero ${ }^{352}$

-Pedro Bermudez de Castro cumplidor y tutor ${ }^{353}$

-Pedro de Luaces prestança $a^{354}$

-Rodrigo de Soo criado

-Rodrigo de [...] mayordomo ${ }^{355}$

-Ruy Calbo juez $z^{356}$

-Ruy de Leis prestança (bis)

-Ruy Gómez notario, salario ${ }^{357}$

-Ruy Lopes Teyxeiro criado $^{358}$

-Ruy Tato pagador (bis)

-Sancho López de Santiso hidalgo y criado de casa ${ }^{359}$

-Vasco Forján clérigo, merced ${ }^{360}$

-"Vnos vonos mançebos"? ?61

Fecha de recepción del artículo: Febrero 2010

Fecha de aceptación y versión final: Junio 2010

${ }^{352}$ Vid. Lorenzo Moñiz y Fernán López de Navia.

${ }^{353}$ Aparece administrando la casa y dando poderes junto con el conde en 1509, en un codicilio de 1510 se menciona que se le han encomendado los hijos del conde. Pasa cuentas en de su administración en 1511, CA, pp. 135-138, 223, 427-436 y 476.

${ }^{354}$ Se trata de un procurador, CA, p. 475.

${ }^{355}$ Citado como mayordomo del conde en la residencia de Burón, CA, p. 229.

${ }^{356}$ Era juez de Soneira en 1507 y tres años después aún mantenía cargo en la misma merindad. CA, p. 336 y vid. Martín de Leis.

${ }^{357}$ Cobraba 1.500 mrs por su oficio en Vimianzo y en Laxe, CA, p. 473.

${ }^{358}$ Vid. Diego de Cabana y Fernando Páez Varela.

${ }^{359}$ Atestigua el testamento, vid. Alonso de Celis. En éste se le dota para casamiento y se indica que junto a Moñiz sirvió especialmente al conde. Ejercería el cargo de juez de Soneira, en 1519, en nombre del conde Lope Osorio de Moscoso, menor de edad; siete años después es merino de Burón manteniendo el oficio en 1527; AGS, Patronato Real, leg. 59, doc. 125 y CA, pp. 135, 236 y 685.

${ }^{360}$ CA, p. 473.

${ }^{361}$ La relación de afinidad está clara puesto que Gutierre de Hevia indica “que azyan muy vyen su servyçio que prendyeran a unos de Navya...que me mando lles dese de bestyr", CA, p. 230. 